UDK: 355.48(497.5Glina)"1991" 355.48(497.5Petrinja)"1991" Prethodno priopćenje Primljeno: 10. 4. 2019.

\title{
Operacija Hrvatske vojske „Vihor” u prosincu 1991. godine
}

\author{
Domagoj Štefančić \\ Hrvatski memorijalno-dokumentacijski centar Domovinskog rata \\ Marulićev trg 21, Zagreb \\ domagoj.stefancic@centardomovinskograta.hr
}

\begin{abstract}
Na temelju izvorne dokumentacije vojnih i civilnih ustanova pobunjenih hrvatskih Srba te postrojbi Jugoslavenske narodne armije prikazano je stanje i djelovanje srpskih snaga, uključujući Jugoslavensku narodnu armiju, na okupiranom prostoru općina Glina i Petrinja, na kojem je u prosincu 1991. izvedena operacija Hrvatske vojske „Vihor”. Opisana su i borbena djelovanja hrvatskih snaga u tom dijelu Pokuplja koja su prethodila operaciji. Dan je temeljit uvid u pripremu i tijek protunapada srpskih snaga, iz kojega je očita njihova nadmoć u artiljeriji i oklopu te doprinos starješina Jugoslavenske narodne armije izvedbi protunapada. Na kraju su izneseni i uspoređeni gubici obiju strana u ljudstvu i borbenim sredstvima, čime su sumirani učinci i posljedice operacije „Vihor”.
\end{abstract}

Ključne riječi: Hrvatska vojska; Jugoslavenska narodna armija; Teritorijalna obrana Srpske autonomne oblasti Krajine; operacija „Vihor”

\section{Uvod}

Pobuna Srba u Hrvatskoj protiv nove, u proljeće 1990. demokratski izabrane vlasti proširila se tijekom kolovoza 1990. iz sjeverne Dalmacije i Like na prostor Banovine. Ministarstvo unutarnjih poslova Republike Hrvatske (MUP RH) naložilo je krajem rujna 1990. svim sekretarijatima unutarnjih poslova (SUP) i stanicama javne sigurnosti da izdvoje $60 \%$ naoružanja rezervnoga sastava policije da bi se mogao naoružati povećani broj pripadnika aktivnoga sastava. ${ }^{1}$ Dio hrvatskih Srba na Banovini 28. rujna 1990. odgovorio je na taj postupak masovnim okupljanjima u Glini, Petrinji i Dvoru na Uni, tijekom kojih su prosvjednici u Glini i Dvoru na Uni uspjeli oteti oružje iz tamošnjih policijskih postaja. Nastavak pobune Srba u Republici Hrvatskoj doveo je 21. prosinca 1990. do proglašenja nelegalne Srpske autonomne oblasti (SAO) Krajine, kojoj se Općina Glina, voljom odbornika srpske nacionalnosti, pridružila

1 BARIĆ, Srpska pobuna u Hrvatskoj, 83. 
31. ožujka 1991., a SUP Glina istodobno je donio odluku o pristupanju SUP-u SAO Krajine, koja se tada nije mogla ostvariti. ${ }^{2}$ Nakon što je Hrvatski sabor 25. lipnja 1991. proglasio samostalnu i suverenu Republiku Hrvatsku, Ratno predsjedništvo Općine Glina proglasilo je ratno stanje, koje je trebalo potrajati sve dok hrvatske snage ne budu protjerane s područja općine. Srpski su pobunjenici već sutradan napali lokalnu policijsku postaju. U sukob se umiješala i oklopna postrojba Jugoslavenske narodne armije (JNA) iz petrinjskoga garnizona stvorivši „tampon-zonu” između sukobljenih snaga. Pripadnici MUP-a RH uspostavili su nadzor nad postajom, u kojoj su se održali do 26. srpnja 1991., kada su Štab Teritorijalne obrane (TO) Glina i kapetan Dragan Vasiljković, komandant kninskih specijalaca, izvodeći operaciju „Žaoka” uz potporu dijela oklopnoga bataljuna JNA napali postaju i primorali hrvatske snage na povlačenje prema Viduševcu. ${ }^{3}$ Budući da se JNA stavila u službu agresije Republike Srbije na Republiku Hrvatsku, sve snage pod njezinim zapovijedanjem i one koje su s njom surađivale tretiraju se u razradi ove teme kao srpske snage.

Od kraja 80-ih godina odvijao se posljednji preustroj Oružanih snaga Socijalističke Federativne Republike Jugoslavije (SFRJ). U preustroju snaga na širem području Zagreba od ukinutih postrojbi JNA te dijelova Riječkoga i Varaždinskoga korpusa ustrojen je 10. zagrebački korpus. Glavne snage korpusa bile su u Zagrebu, Jastrebarskom, Dugom Selu i Petrinji. U garnizonu Petrinja bilo je naoružanje i oprema za 257. i 622. motoriziranu brigadu, 6. mješoviti artiljerijski puk i 6 . mješoviti artiljerijski protuoklopni puk. U funkciji je bio samo jedan motorizirani bataljun ročne vojske u 622. motoriziranoj brigadi, pa je u svibnju 1991. garnizon ojačan dovođenjem oklopnoga bataljuna 51. mehanizirane brigade iz Pančeva. U Glini je nadalje krajem lipnja 1991. osnovano Izdvojeno komandno mjesto 10. zagrebačkoga korpusa na čelu s pukovnikom Grujom Borićem. ${ }^{4}$

U sklopu napadne operacije JNA protiv Republike Hrvatske 25. rujna osnovana je 1. operativna grupa (1. OG) za zapovijedanje oružanim sastavima JNA i Teritorijalne obrane pobunjenih Srba na Banovini i Kordunu. ${ }^{5}$ Komanda 1. OG bila je uglavnom sastavljena od oficira iz Centra visokih vojnih škola iz Beograda. Na dužnosti komandanta bio je general-major Dušan Koturovićc,

\footnotetext{
2 Isto, 97; RUŽIĆ, „Politički i vojno-sigurnosni aspekt zbivanja u glinskoj općini 1990. 1991., 718.

3 RUŽIĆ, „Politički i vojno-sigurnosni aspekt zbivanja u glinskoj općini 1990. - 1991., 719, 725; MARIJAN, Domovinski rat, 125-126.

4 MARIJAN, Domovinski rat, 122; MARIJAN, Smrt oklopne brigade, 164, 252.

5 MARIJAN, Domovinski rat, 122; HR-HMDCDR-2, kut. 6048, Iskustva u dosadašnjim borbenim djelovanjima 1 . OG, nedatirano.

6 Dušan Koturović (Ub, Srbija, 1. svibnja 1953.), general-major JNA, Srbin. Tijekom službe u JNA bio na dužnosti komandanta divizijuna, komandanta puka, načelnika štaba divizije, načelnika štaba, ujedno zamjenika komandanta 6. proleterske pješadijske divizije 5. armije, načelnika Školskoga centra artiljerije i načelnika Uprave artiljerije GŠ JNA (do 8. svibnja 1992.). NAZOR, BRIGOVIĆ, Zapovjedni vrh JNA, 301.
} 
a od sredine listopada 1991. general-major Špiro Niković.7 Operativna grupa imala je zadatak deblokirati snage JNA u Karlovcu i omogućiti izvlačenje postrojbi 5. vojne oblasti JNA sa širega zagrebačkog područja. U drugoj polovini listopada sastav 1. OG bio je sljedeći: 9. motorizirana brigada, 592. motorizirana brigada, 622. motorizirana brigada, 389. raketno artiljerijska brigada, 580. mješovita artiljerijska brigada, 17. partizanska brigada, 6 . mješoviti protuoklopni artiljerijski puk, 6. mješoviti artiljerijski puk, 1. oklopni bataljun 51. mehanizirane brigade, Taktička grupa 1 te postrojbe i općinski štabovi Teritorijalne obrane u sastavu Štaba TO 2. i 3. operativne zone za Baniju i Kordun. ${ }^{8}$ Na prilazima Karlovcu djelovala je 9. motorizirana brigada iz Zaječara, a 592. motorizirana brigada stigla je iz Kumanova u Glinu 23. listopada, bez 1. motoriziranog bataljuna, koji je djelovao na bojištu sjeverne Dalmacije u sastavu 9. korpusa JNA. ${ }^{9}$ Brigada je polovinom studenoga 1991. imala u svojem sastavu tenkovsku četu T-55 i haubičko-artiljerijski divizijun $155 \mathrm{~mm} .{ }^{10}$ Od studenoga 1991. pančevački oklopni bataljun tenkova M-84 stavljen je pod izravno zapovjedništvo 1 . OG kao njezina interventna pričuva. ${ }^{11}$

U rujnu 1991. srpske snage na Banovini - postrojbe JNA i lokalni odredi Teritorijalne obrane - uspjele su zauzeti gradove Petrinju, Hrvatsku Kostajnicu i Topusko. U glinskoj je općini padom Gornjega Viduševca 30. rujna došlo do sloma hrvatske obrane i prodora srpskih snaga sve do rijeke Kupe. Plan Komande 1. OG bio je izbiti na Kupu između Petrinje i Karlovca i omogućiti izvlačenje postrojbi JNA iz Zagreba i Samobora. Taktička grupa 1, u čijem su sastavu bili 2. i 3. odred TO Glina, trebala je razbiti hrvatske snage i izbiti na Kupu, a potom su postrojbe Teritorijalne obrane trebale posjesti desnu obalu Kupe i organizirati obranu. Komanda 1 . OG u svojoj analizi zaključila je da je upravo ta grupa postigla najveći uspjeh i ostvarila svoj zadatak. ${ }^{12}$

Naoružani sastavi pobunjenih Srba bili su iz struktura MUP-a RH koje su se odmetnule i postale sastavni dio milicije SAO Krajine te sastava Teritorijal-

7 Špiro Niković (Krnjice, Bar, Crna Gora, 1936.), general-potpukovnik, Crnogorac. Komandant 1. operativne grupe, potom komandant 10. bihaćkoga korpusa (30. prosinca 1991. - 8. svibnja 1992.). Isto, 307.

8 MARIJAN, Domovinski rat, 122; NAZOR, BRIGOVIĆ, Zapovjedni vrh JNA, 215; RUPIĆ, Republika Hrvatska i Domovinski rat, 398-399.

9 MARIJAN, Smrt oklopne brigade, 164-165; MARIJAN, „102. brigada HV Novi Zagreb”, 26; BRIGOVIĆ, RADOŠ, Republika Hrvatska i Domovinski rat, 311-312, 382; NAZOR, BRIGOVIĆ, Zapovjedni vrh JNA, 190; HR-HMDCDR-2, kut. 6048, Iskustva u dosadašnjim borbenim djelovanjima 1 . OG, nedatirano.

10 HR-HMDCDR-2, kut. 6048, Iskustva u dosadašnjim borbenim djelovanjima 1. OG, nedatirano; HR-HMDCDR-199, kut. 25, Zapovijed komandanta 592. mtbr za obranu br. 1, Komanda 592. mtbr, pov. br. 15-172, 10. 11. 1991.; Zapovijed artiljerije br. 2 načelnika artiljerije u obrani, Komanda 592. mtbr, str. pov. br. 15-187/1, 15. 11. 1991.; MARIJAN, Domovinski rat, 122; MARIJAN, „102. brigada HV Novi Zagreb”, 25.

11 MARIJAN, Smrt oklopne brigade, 165.

12 HR-HMDCDR-2, 24. pješačka brigada Glina, kut. 1, Plan obilježavanja važnijih datuma u 24. pješačkoj brigadi; HR-HMDCDR-2, kut. 6048, Iskustva u dosadašnjim borbenim djelovanjima 1. OG, nedatirano; RUPIĆ, Republika Hrvatska i Domovinski rat, 340-343. 
ne obrane, koja je nastala izravno iz prostorne strukture Teritorijalne obrane Republike Hrvatske, a u rujnu 1991. bila je organizirana u pet općinskih štabova Teritorijalne obrane i 16 odreda. ${ }^{13}$ Za operativno zapovijedanje Teritorijalnom obranom osnovana je Operativna zona za Baniju i Kordun. Štab TO 2. i 3. operativne zone za Baniju i Kordun imao je sjedište u Vojniću, poslije u Topuskom (prvotno 2. i 3. operativna zona, potom samo 3. operativna zona). ${ }^{14} \mathrm{U}$ skladu s ustaljenom praksom u Oružanim snagama SFRJ, od 19. listopada sve su postrojbe Teritorijalne obrane na prostoru Korduna i Banovine podređene Komandi 1. OG te je određeno da se upotrebljavaju „kao organski sastav jedinica JNA u zonama borbenih dejstava”. ${ }^{15} \mathrm{Na}$ Banovini su djelovale i paravojne skupine koje su se predstavljale kao „specijalne jedinice”. Kao takva se na glinskom području isticala skupina Siniše Martića „Šilta”. Njezinu je jezgru činilo dvadesetak civila iz Gline i okolice koji su u travnju 1991. završili specijalni policijski tečaj SUP-a SAO Krajine u Golubiću kraj Knina. ${ }^{16}$

Ujesen 1991. u sklopu preustroja Teritorijalne obrane pobunjenih Srba počelo je osnivanje brigada od dotadašnjih odreda pri općinskim štabovima. Prvoga studenog osnovana je 1. brigada TO Glina „Dragiša Stefanović”. Njezino formiranje bilo je otežano zbog nedostatka utvrđene formacije, naoružanja i opreme. Glinska je brigada imala poteškoća s popunom ljudstvom, njezini starješine nisu bili dovoljno osposobljeni za vođenje postrojbi, a bilo je i samovoljnoga napuštanja položaja kao i drugih oblika nediscipline. ${ }^{17}$ Brigadom je zapovijedao potpukovnik Marko Vrcelj, ${ }^{18}$ a zamjenik mu je bio potpukovnik Petar Grabundžija. U sjevernom, pokupskom dijelu glinske općine prevladavala su naselja s hrvatskom većinom. Sela Zaloj, Gračanica i Stankovac postati će ujesen 1991. poprište borbi na tom dijelu banovinskoga bojišta.

Nasuprot srpskim snagama djelovale su postrojbe hrvatske policije i vojske. Za Banovinu je bila nadležna Policijska uprava Sisak. Po bojnoj vrijednosti posebno se isticala njezina Posebna jedinica policije „Osa”, osnovana 15. ožujka 1991. godine. Zapovjedništvo Zbora narodne garde (ZNG) za Baniju i Kordun osnovano je 26. srpnja 1991. i u listopadu preimenovano u Zapovjedništvo Operativne grupe za Sisak i Baniju (OGSB) sa sjedištem u Sisku. Na nje-

13 MARIJAN, Domovinski rat, 122-123.

14 RADELIĆ et al., Stvaranje hrvatske države i Domovinski rat, 104-105.

15 RUPIĆ, Republika Hrvatska i Domovinski rat, 398-399.

16 BARIĆ, Srpska pobuna u Hrvatskoj, 334; RUŽIĆ, „Politički i vojno-sigurnosni aspekt zbivanja u glinskoj općini 1990. - 1991., 731.

17 HR-HMDCDR-2, 3. operativna zona TO SAO Krajina, kut. 1, Izvješće Štaba TO 3. operativne zone za Baniju i Kordun o stanju u 1. brigadi TO, Štab TO 3. operativne zone Banija i Kordun, br. 293, 25. 12. 1991.; 1. brigada TO, kut. 1, Zahtjev za oslobađanje od dužnosti komandanta 1. brTO „DS” Glina, Komanda 1. brigade TO Glina, str. pov. br. 01-46/6, 22. 12. 1991.; RUŽIĆ, „Politički i vojno-sigurnosni aspekt zbivanja u glinskoj općini 1990. - 1991., 726.

18 Marko Vrcelj (Benkovac, 10. travnja 1950.), završio Vojnu akademiju u Beogradu i Zadru. Godine 1991. bio je na dužnosti nastavnika u Centru vojnih škola u Beogradu, odakle odlazi na banovinsko ratište, a potom na dužnost u Knin, gdje je dočekao slom Republike Srpske Krajine. VRCELJ, Rat za Srpsku Krajinu, 254; HR-HMDCDR-2, 1. brigada TO Glina, kut. 1, Podaci za starješine, Komanda 1. brigada TO Glina, str. pov. br. 06-65/1, 24. 12. 1991. 
govu čelu bili su umirovljeni general Janko Bobetko i pukovnik Božo Budimir. Operativna grupa sastojala se od Zapovjedništva i pristožernih postrojbi, 2. A brigade ZNG-a „Gromovi”, sisačkoga 57. samostalnog bataljuna, 120. brigade (Sisak), 1. mješovitoga artiljerijskog divizijuna, 1. mješovitoga protuoklopnog divizijuna, 55. lakoga artiljerijskog divizijuna protuzračne obrane, 36. inženjerijsko-pontonirskog bataljuna „Dabar”, Odreda „Braća Radić”, Riječne ratne flotile, Samostalne turopoljske čete, Samostalne čete Odra, voda atomskobiološko-kemijske obrane, Vojne policije, Snaga Sunje, petrinjskoga 74. i 80. samostalnog bataljuna i glinskoga 78. samostalnog bataljuna. Do kraja 1991. na Banovini su angažirani dijelovi 1. A brigade ZNG-a, 99. brigade (ZagrebPešćenica), 144. brigade (Zagreb-Sesvete), 145. brigade (Zagreb-Dubrava), jedna bojna 100. brigade (Zagreb-Centar) te pričuvna bojna ZNG-a iz Novoga Zagreba. ${ }^{19}$ Prvoga listopada 1991. teritorij Republike Hrvatske podijeljen je na šest operativnih zona i dva sektora. Prostor Banovine ušao je u zonu odgovornosti 3. operativne zone Zagreb, kojom je zapovijedao pukovnik Stjepan Mateša. Sve oružane postrojbe i zapovjedništva na području 3. operativne zone podređeni su njezinu zapovjedniku. ${ }^{20}$

Među nabrojenim postrojbama borbeno najjača, prokušana u borbama tijekom ljeta 1991. na Banovini, bila je 2. A brigada ZNG-a. Bila je jedna od četiri profesionalne brigade ZNG-a koje su ustrojene 15. svibnja 1991. godine. Isprva je popunjavana pripadnicima specijalne policije iz Kumrovca, Vinice i Rakitja. U borbama kod Novoga Farkašića, Slane, Glinske Poljane i Međurača "Gromovi” su, unatoč nedovoljnoj popunjenosti, pokazali borbenu učinkovitost potiskujući srpske snage. Prema zapovijedi Glavnoga stožera Hrvatske vojske (HV) od 25. listopada 1991. u „A” brigadama ZNG-a započelo je ustrojavanje oklopno-mehaniziranih bojni. Oklopno-mehanizirana bojna 2. A brigade, kojom je zapovijedao Ivan Čeak, osnovana je 31. listopada po naredbi Operativne zone Zagreb, a bila je raspoređena na liniji od Pokupskoga do Blinjskoga Kuta. ${ }^{21}$

Borbe u glinskom i petrinjskom Pokuplju ujesen 1991.

Po izbijanju na Kupu srpske snage pokušale su zauzeti preostala područja s desne strane rijeke pod kontrolom hrvatskih snaga. Postrojbe JNA sa srpskim teritorijalcima iz Gline i Petrinje napale su 17. listopada područje nebojanskoga džepa, odnosno Novi Farkašić, gdje su doživjele poraz. Sutradan su pripadnici 1. bojne 2. A brigade iskoristili postignuti uspjeh i napali teritorijalce $i$ oklopnu postrojbu JNA. Poginula su dva pripadnika TO Glina i jedan pripad-

19 MARIJAN, Domovinski rat, 121-122; ANDRES et al., 120. brigada $H V$-a „Ban Toma Ba$k a c c^{\prime \prime}, 247$.

20 BRIGOVIĆ, RADOŠ, 101. brigada $H V-a, 23$.

${ }_{21}$ LUCIĆ, 2. gardijska brigada Hrvatske vojske Gromovi, 34, 36, 46, 48-49, 67, 69; HODALJ, „102. brigada HV u operaciji Vihor 1991. godine”, 24; ANDRES et al., 120. brigada HV-a „Ban Toma Bakač", 126. 
nik JNA, a ranjeno je 30 boraca, od kojih 14 iz TO Glina. Zarobljena su četiri tenka, motorna vozila i velika količina streljiva. Nakon neuspjeha kod Novoga Farkašića snage 1. OG bile su uglavnom u obrani, a hrvatske postrojbe, iako slabije, bile su borbeno aktivnije. ${ }^{22}$ Hrvatske su snage 22. listopada iznenadnim napadom oslobodile sela Vratečko, Slana, Međurače i Mokrice te napredovale prema Glinskoj Poljani (na okupiranom prostoru općine Petrinja), iz koje su se potom povukle na bolje položaje u Slani. ${ }^{23}$

U Glavnom stožeru HV-a nakon uspjeha kod Novoga Farkašića zaključeno je da je moguće izvesti napad kojim bi se razbile i potisnule srpske snage na desnoj obali Kupe. ${ }^{24}$ U zapovijedi za napad određeno je da snage 10 . brigade TO (Velika Gorica) i 101. brigade (Susedgrad) uz topničku i tenkovsku potporu potisnu srpske snage i prvoga dana napada dosegnu crtu Slana - Donje Taborište - Čremušnica. Prijelaz na Kupi kod Šišinca bio je na pomoćnom smjeru napada, na kojem je trebala djelovati 2 . bojna 10 . brigade. ${ }^{25} \mathrm{U}$ zoni napada hrvatskih snaga bile su postrojbe Štaba TO Glina, odnosno dvije čete glinskoga 2. odreda TO koje su posjele položaje za obranu u području Radočaji - Sveto Trojstvo, a dvije ojačane čete 3 . odreda TO zaposjele su položaje na području Slatina Pokupska - Stankovac. ${ }^{26}$

Hrvatski je napad započeo 28. listopada 1991. snažnom topničkom pripremom duž desne obale Kupe od Gračanice Šišinečke preko Slatine Pokupske do Čremušnice. S obzirom na to da se pripadnici 3. bojne 10. brigade nisu pojavili kod mosta, diverzantski vod 101. brigade pokušao je prvi prijeći Kupu, što zbog snažna srpskoga otpora nije ostvareno. U drugom pokušaju, uz pomoć tenka i transportera iz 55. oklopne satnije, diverzanti uspijevaju prijeći most i osigurati mostobran, a za njima prelaze dijelovi 101. brigade. Do popodnevnih sati pripadnici diverzantskoga voda i 1. bojne 101. brigade ovladali su Slatinom Pokupskom, Andrijevićima i Zalojem ušavši 3 do 5 kilometara u okupirani prostor. Druga i treća bojna 10. brigade prešle su Kupu 29. listopada na području od Zaloja do Pokupske Slatine. Suočene s nadmoćnim srpskim snagama, te su se postrojbe do oko 3 sata 31 . listopada povukle na lijevu obalu Kupe. Time je okončan prvi pokušaj forsiranja rijeke u Domovinskom ratu. Hrvatske postrojbe imale su dva poginula i desetak ranjenih vojnika. ${ }^{27} \mathrm{Nepo-}$

${ }^{22}$ LUCIĆ, 2. gardijska brigada Hrvatske vojske Gromovi, 184-191; RUPIĆ, Republika Hrvatska i Domovinski rat, 397-398; STIPČIĆ, Zagrebački korpus Zbora narodne garde, 122; MARIJAN, Slom Titove armije, 302-303; HR-HMDCDR-2, kut. 6048, Iskustva u dosadašnjim borbenim djelovanjima $1 . \mathrm{OG}$, nedatirano.

23 MARIJAN, Domovinski rat, 130; MARIJAN, Jugoslavenska narodna armija u ratu protiv Republike Hrvatske, 135; LUCIĆ, 2. gardijska brigada Hrvatske vojske Gromovi, 193-197.

24 MARIJAN, Domovinski rat, 138; BUDIMIR, Rat i sloboda, 132.

25 BRIGOVIĆ, RADOŠ, 101. brigada $H V-a, 67$.

26 HR-HMDCDR-2, ŠTO Glina, kut. 1, Zapovijest za obranu komandanta TOO Glina operativni broj 3. za dan 24. 10. 1991., Štab TO Glina, str. pov. br. 01-7-3, Glina, 22. 10. 1991.

27 Opširnije u: BRIGOVIĆ, RADOŠ, 101. brigada $H V$-a, 67-80; MARIJAN, Domovinski rat, 138; BOŽIĆ, GORŠETA, 153. velikogorička brigada HV, 190-203; STIPČIĆ, Zagrebački korpus Zbora narodne garde, 126-127; HR-HMDCDR-2, ŠTO Glina, kut. 1, Zapovijest za obranu komandanta TOO Glina operativni broj 3. za dan 24. 10. 1991., Štab TO Glina, str. pov. br. 01-7-3, Glina, 22. 10. 1991. 
kretanje postrojbi $\mathrm{HV}$-a s područja Lasinje i Nebojana u napad prepoznato je kao veliki problem i jedan od razloga neuspjeha te manje napadne operacije. Sama operacija bila je iznad tadašnjih mogućnosti hrvatskih postrojbi, a srpske snage dovoljno jake u pružanju otpora, što se na mnogo teži način očitovalo u prosinačkom pokušaju forsiranja Kupe.

Hrvatske su snage 14. studenog 1991. na području nebojanskoga džepa na pravcu Vratečko - Slana izvele napad bez uspjeha. Komanda 1. OG stoga je sa 592. motoriziranom brigadom zatvorila pravac od Vratečka i pojačala obranu Graberja. Njezin lijevi susjed bio je, duž rijeke Gline, na području Donjih i Gornjih Jama te Male Soline, 2. bataljun glinske brigade. Prema radnoj karti 592. brigade, ona je na područje Slane i Glinske Poljane razmjestila postrojbe 1. motoriziranog bataljuna, pri čemu je 2. motorizirana četa držala prednji kraj u Slani. Oklopni bataljun nalazio se u Graberju, a izviđačka četa u Marinbrodu. Brigadna artiljerijska grupa bila je razmještena u Novom Selu Glinskom. ${ }^{28}$

Stanje i raspored srpskih snaga uoči „Vihora”

Novinarska ekipa beogradske Politike posjetila je 9. prosinca 1991. prvu crtu na Kupi, gdje su susreli pripadnike 592. motorizirane brigade, od kojih su doznali stanje na tom dijelu banovinskoga bojišta. Vojnici su bili gotovo dva mjeseca na položajima u sukobu s hrvatskim postrojbama, a među njima je bilo i dobrovoljaca. Opskrba prve crte bila je otežana, pa su se streljivo i hrana dostavljali i konjskom zapregom. Sedmoga prosinca iz te je brigade na hrvatsku stranu prešlo 11 vojnika (šest Hrvata i pet Albanaca). ${ }^{29}$ Dopis 1 . OG od 7. prosinca kaže pak da je iz 1. brigade TO i 592. motorizirane brigade pobjeglo devet vojnika, koji su uhvaćeni i vraćeni u svoje postrojbe. Radilo se o vojnicima kojima je isteklo služenje vojnoga roka, no morali su doslužiti još do 60 dana. ${ }^{30}$

Od 24. studenog glinska je brigada organizirala obranu na Kupi, koju je održavala s tri vlastita bataljuna. Glavne snage brigade pritom su bile na pravcu selo Slatina - selo Taborište - grad Glina, a pomoćne na pravcima selo Stankovac - selo Prekopa i selo Ilovačak - selo Golinja. Odsudnom obranom, koristeći zemljišne objekte, trebalo je spriječiti nasilni prelazak i prodor „ustaških snaga". ${ }^{31}$ Spisi brigade pružaju nam uvid u stanje njezinih postrojbi na prvoj crti pred pokretanje operacije HV-a. U svim bataljunima brigade i dalje je po-

28 HODALJ, „102. brigada HV u operaciji Vihor 1991. godine”, 17; RUPIĆ, Republika Hrvatska i Domovinski rat, 466-467; STIPČIĆ, Zagrebački korpus Zbora narodne garde, 122; HRHMDCDR-2, Radna karta - raspored postrojbi 592. motorizirane brigade.

${ }_{29}$ HR-HMDCDR-18, „Branimo Jugoslaviju tamo gde treba”, Politika (Beograd), 10. 12. 1991., 9; HR-HMDCDR-199, kut. 5, Izvješće Organa bezbjednosti 1. OG, str. pov. br. 1-52, 8. 12. 1991.; LUCIĆ, 2. gardijska brigada Hrvatske vojske Gromovi, 197.

30 Dopis Organa bezbjednosti Komande 1. OG Organu bezbjednosti 5. VO i Upravi bezbjednosti SSNO-a, str. pov. br. 1-50, 7. 12. 1991., u: PANDŽA, Krajina kroz dokumente, 136; RUPIĆ, Republika Hrvatska i Domovinski rat, 533-534.

31 MARIJAN, „102. brigada HV Novi Zagreb”, 26. 
stojao problem inženjerijskoga osiguranja prve crte iako je već 1. prosinca izdana zapovijed za izradu zaklona i poduzimanje raznovrsnih mjera kako bi se pružio snažan otpor „... da se spreči njihov prelazak preko reke Kupe”. U njoj se tražila izrada osnovnoga i dva do tri rezervna položaja, povezivanje odjeljenja u vodu rovovima i komunikacijama, postavljanje žičanih prepreka osiguranih protupješačkim minama, utvrđivanje kuća kao otpornih točaka, zatvaranje međuprostora između vodova i odjeljenja žičanim i minskim preprekama te uvezivanje svih sredstava u jedinstveni vatreni sustav kojim bi komandant brigade mogao raspolagati u svakoj prilici. Vojnici su također upozoreni da se sljedećih dana očekuje velika hladnoća i snijeg, pa je trebalo učiniti sve da bi se spriječilo bilo kakvo iznenađenje. Sedmoga prosinca brigadni su starješine obišli bataljune radi uvida u stanje i provedbu mjera koje je naložio komandant brigade. Uočena je nedovoljna popunjenost ljudstvom i nedovoljno inženjerijsko uređenje prednjega kraja. Devetoga prosinca "grupa ustaša” pokušala se ubaciti u Donje Jame. Teritorijalci su ih pustili preko mosta na rijeci Glini, a zatim otvorili vatru i ubili dva hrvatska vojnika. Dan prije pokreta hrvatskih snaga načelnik štaba brigade obišao je 1. bataljun, oficir za operativno-nastavne poslove 2 . bataljun, a 3. bataljun načelnik za obavještajne poslove. Nakon provedenoga izvida zaključeno je da inženjerijsko osiguranje tih postrojbi brigade i dalje nije odgovarajuće. Toga 11. prosinca komandu glinske brigade posjetio je komandant 1 . OG general-potpukovnik Špiro Niković. ${ }^{32}$

U samoj Gračanici pripadnici 3. čete 3. bataljuna glinske brigade bili su raspoređeni na više mjesta u naselju. U jednoj se kući od Stankovca prema Zaloju nalazio zamjenik komandanta čete Stevan Šikanja sa 9-11 vojnika; 100 metara dalje prema Zaloju, kod prvoga odvojka lijevo, bio je komandant čete potporučnik Nenad Borojević s izvjesnim brojem vojnika, a na sljedećih 100 metara još jedna grupa te na vrhu sela grupa boraca s komandantom odjeljenja Vasićem. ${ }^{33}$ Artiljerijsku podršku tim postrojbama osiguravalo je topništvo 592. i 622. motorizirane brigade te glinske brigade (baterije minobacača raznih kalibara; baterija netrzajnih topova; baterija topova $76 \mathrm{~mm} \mathrm{B-1;} \mathrm{baterija} \mathrm{hau-}$ bica $105 \mathrm{~mm}$ u Golinji; baterija haubica $155 \mathrm{~mm}$; baterija višecijevnih raketnih bacača i laka protuavionska artiljerijska baterija). ${ }^{34}$

32 HR-HMDCDR-2, 1. brigada TO Glina, kut. 1, Zapovijed Komande 1. brTO za izradu borbenih dokumenata i uređenje obrambenih rejona, str. pov. br. 01-34-1, Glina, 1. 12. 1991.; Ratni dnevnik 1. brigade TO Glina.

33 HR-HMDCDR-199, kut. 8, Izvješće operativnog tima Organa bezbjednosti, Organ bezbjednosti 7. OG, str. pov. br. 8-60, 22. 3. 1992.

34 RUPIĆ, Republika Hrvatska i Domovinski rat, 466-467; HR-HMDCDR-2, 1. brigada TO Glina, kut. 1, Molba za prijem u jedinicu javne bezbjednosti Komandi 1. brigade TO Glina, 26. 2. 1992.; Popisi postrojbi mješovitog artiljerijskog divizijuna 1. brigade TO Glina; Informacija o stanju u 1. brigadi TO, Komanda 1. brigade TO Glina, pov. br. 02-21/5, 12. 1. 1992. 


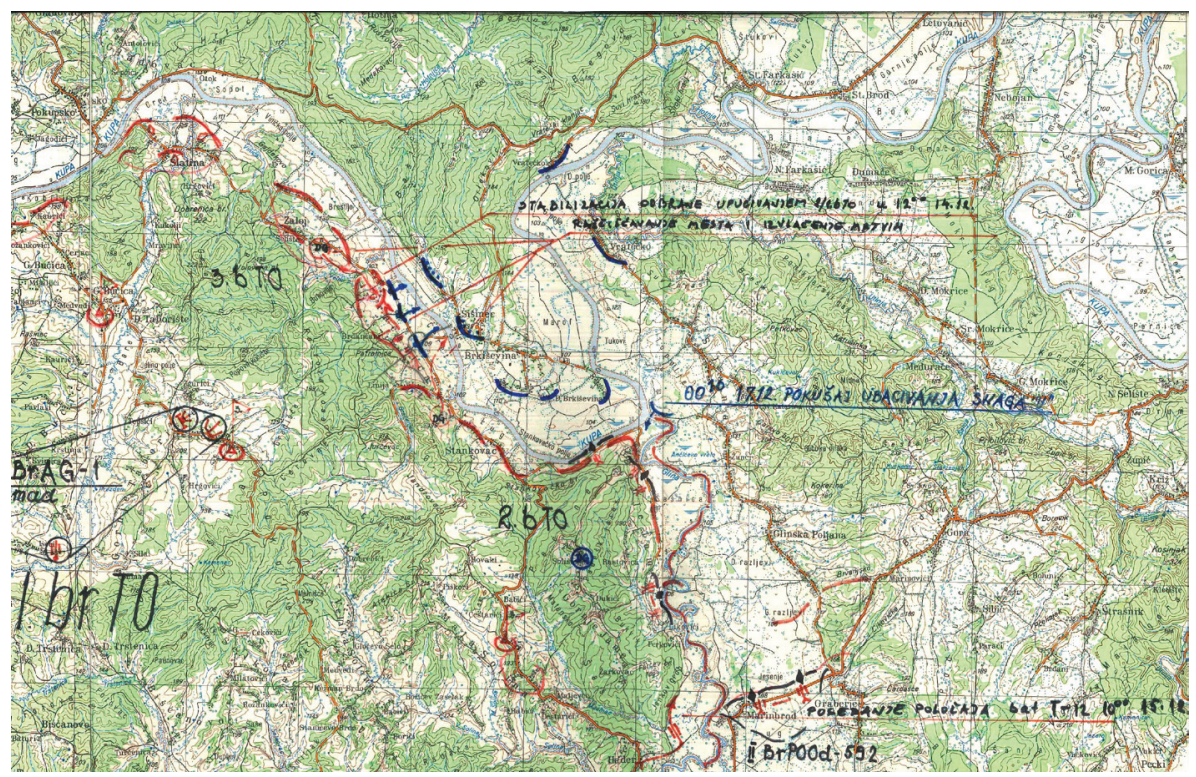

Karta 1. Razmještaj srpskih snaga na kupi uoči operacije „Vihor“

Drugi hrvatski pokušaj prelaska Kupe - operacija „Vihor”

Priprema operacije

Zapovjedništvo Operativne grupe za Sisak i Baniju napisalo je 9. prosinca 1991. zapovijed za provedbu napadne operacije prema kojoj je udarima izviđačko-diverzantskih grupa i snažnom vatrenom pripremom trebalo srpskim snagama nanijeti što veće gubitke. Zapovijed je priopćena na sastanku zapovjednika OGSB-a i podređenih postrojbi 11. prosinca u večernjim satima na zapovjednom mjestu OGSB-a u Sisku. Operacija je trebala biti ostvarena brzim prodorom na dva glavna i više pomoćnih pravaca pomoću oklopno-mehaniziranih postrojbi. Glavni pravci bili su: selo Stankovac - selo Viduševac i selo Mokrice - Pribilović brdo - selo Gora - selo Sibić, a pomoćni: selo Pokupsko - selo Gornja Bučica - selo Gornje Taborište, Gajdekovo - selo Slatina, selo Gračanica - Pokule - selo Gornje Taborište, Stankovačko brdo - selo Mala Solina - selo Dvorišće, ušće rijeke Gline - Glina - selo Gornje Jame selo Hađer i selo Slana - selo Glinska Poljana - selo Graberje. Za operaciju su angažirane sljedeće snage: 2 . A brigada "Gromovi”, 100. brigada, 102. brigada, 120. brigada, 144. brigada, 145. brigada, 153. brigada (bivša 10. brigada TO), 36. inženjerijsko-pontonirski bataljun „Dabar”, 57. samostalni bataljun, 74. samostalni bataljun, 78. samostalni bataljun, Riječna ratna flotila i snage obrane Sunje. Radi rasterećenja snaga u napadu planirano je sudjelovanje 140. brigade (Jastrebarsko) iz smjera Donje Kupčine na pravcu selo Špehari - Novo Selo Lasinjsko, kao i 148. brigade (Zagreb-Trnje) iz smjera Lijevih Štefanaka 
na pravcu Gvojići - Karasi tijekom 13. prosinca. ${ }^{35}$ Zapovjedništvo Operativne zone Zagreb podredilo je 11. prosinca 153. brigadu Zapovjedništvu OGSB-a. ${ }^{36}$

Operativna grupa za Sisak i Baniju ojačana je 6. prosinca 102. brigadom (Novi Zagreb), koja je u njezinu zonu odgovornosti stigla sa 1953 pripadnika, od čega 575 vojnika u 1. bojni, 550 u 2. bojni te 527 u 3. bojni. Brigada je uoči operacije „Vihor” provela uvježbavanje nasilnoga prelaska rijeke na rijeci Odri od 8. do 10. prosinca. U operativnom rasporedu brigada je bila jedina slobodna postrojba izvan dodira sa srpskim postrojbama. Zapovjednik 102. brigade dobio je naredbu na uvid oko 22 sata 11. prosinca. Brigada je sa 78. samostalnim bataljunom trebala nasilno prijeći Kupu kod Šišinca i mosta prijeko rijeke Gline, na glavnom pravcu Stankovac - Viduševac i pomoćnom pravcu ušće Gline - Gornje Jame - Hađer. Nakon zauzimanja zapovjeđene crte trebala je primjenom masovnoga zaprečivanja i utvrđivanja spriječiti protunapad oklopno-mehaniziranih postrojbi iz pravca Vrginmosta i Gline. ${ }^{37}$

Uoči pokretanja operacije, prilikom referiranja zapovjednika postrojbi, najveću spremnost za uspješno izvršenje zadataka iskazivali su zapovjednici 153. brigade i oklopno-mehaniziranoga bataljuna 2. A brigade. Valja reći i da je do 10. prosinca u čitavoj operativnoj zoni izgrađen stacionarni sustav žičnih veza te su svaki položaj i zapovjedništvo imali žičnu vezu kojom su se mogli javiti operativnom organu u OGSB-u. ${ }^{38}$ Inženjerijsko-pontonirski bataljun pripremio je sredstva za prijelaz rijeke u Šišincu, nasuprot Gračanici i u području Gajdekova (sjeverozapadno od Zaloja). Za prijevoz vozila na desantnom mjestu prijelaza kod Šišinca korišteni su jedna skela na vlastiti pogon i jedan plivajući transporter (PTS). ${ }^{39}$ Napad iz pokreta forsiranjem rijeke smatra se jednim od najzahtjevnijih vojnih pothvata jer su rijeke sa svim svojim prirodnim obilježjima vrlo ozbiljna prepreka. ${ }^{40}$

Prvi dan - napad hrvatskih snaga

Operacija je započela između 2 i 3 sata ujutro 12. prosinca 1991. prelaskom pripadnika Posebne jedinice policije Policijske uprave Sisak „Osa” i izvidničko-diverzantske skupine 78. samostalnog bataljuna na desnu obalu Kupe. Sisačke „Ose” angažirale su 101 specijalca te 11 policijskih pričuvnika, a Glinski bataljun imao je stotinjak boraca. Vođeni dvojicom glinskih izviđača, specijal-

35 MARIJAN, „102. brigada HV Novi Zagreb”, 28-29; MARIJAN, Domovinski rat, 131, 139; HODALJ, „102. brigada HV u operaciji Vihor 1991. godine”, 18-19, 24.

36 MARIJAN, „102. brigada HV Novi Zagreb”, 29.

37 Isto, 27, 29; HODALJ, „102. brigada HV u operaciji Vihor 1991. godine”, 18-19, 22-23.

38 GAŠLJEVIĆ, „Dnevnik jednog tekuta”, 235, 257.

39 MARIJAN, Domovinski rat, 131; MARIJAN, „102. brigada HV Novi Zagreb”, 30; DIMITRIJEVIĆ, Modernizacija i intervencija jugoslovenske oklopne jedinice, 289; HODALJ, „102. brigada HV u operaciji Vihor 1991. godine”, 21. Uočljivo je da se u prikazu postrojbe izbjeglo precizno opisati njezino djelovanje u ovoj operaciji. Siniša HALUŽAN, „Dabrovi”, Hrvatski vojnik (Zagreb), 12. 3. 1992., 71-73.

40 SABOLOVIĆ, SIKIRIĆ, VUKOVIĆ, „Teorijski pregled vojno-geografskih analiza”, 51. 
ci su prošli minsko polje i ušli u neprijateljsku pozadinu, pri čemu su u jednom trenutku propustili vojni kamion sa srpskim vojnicima. Prešavši cestu, uspeli su se dvjestotinjak metara na brdo Patrolnicu ponad Gračanice. U napad su krenuli podijeljeni u dvije skupine, jedna prema Stankovcu, a druga prema Gračanici. Radi uspješnijega djelovanja specijalci su eksplozivom uništili drveni most prema Zaloju. ${ }^{41}$

Između 5 i 6:30 glinski teritorijalci začuli su zvuke tenkova i pucanje iz pješačkoga oružja te primijetili prebacivanje vojske preko rijeke. Pritom su bili izloženi jakoj strojničkoj vatri, na koju su uzvratili, pa je ona ubrzo prestala. Oko 6:50 čula se i jaka paljba na početku i kraju Zaloja. Grupa teritorijalaca uputila se prema kući gdje je trebala biti skupina boraca s Vasićem, komandantom odjeljenja, no ondje je ustanovljeno da su izuzev jednoga borca svi napustili smještaj i otišli u nepoznatom pravcu. ${ }^{42}$

Krenuvši na Gračanicu, skupina specijalaca imala je tijekom razmjene vatre jednoga poginulog suborca, ne uspijevajući neutralizirati srpski otporni punkt na kraju sela. Specijalci su slomili otpor u jednoj kući djelujući bombama i tromblonima. U Stankovcu je pak došlo do kraćega otpora, a potom su se glinski teritorijalci povukli iz sela. ${ }^{43}$ Rijeku Kupu nakon toga je prešla i oklopno-mehanizirana skupina, odnosno tenkovska satnija 2. A brigade. Tenkovi i dio pješaštva krenuli su prema Maloj Solini, gdje su u zaseoku Babići zaustavljeni topničkom vatrom, zbog čega su primorani na povlačenje u Stankovac. ${ }^{44}$ Posljednja otporna točka (kuća) u Gračanici, kod koje je toga jutra poginuo pripadnik „Osa”, pogođena je tenkovskom granatom, na što su specijalci upali i slomili otpor. Sisački su se specijalci nakon izvršenja toga zadatka istoga dana oko 15 sati vratili u svoju bazu. ${ }^{45}$

Prve vijesti o nasilnom prelasku hrvatskih snaga preko Kupe kod Gračanice komandant glinske brigade potpukovnik Vrcelj dobio je u 8:30 iz Taborišta od komandanta 3. bataljuna rezervnoga kapetana Dušana Gavrilovića. To potvrđuje i podatak s radne karte glinske brigade, na kojoj je stajalo da je u navedeno vrijeme ubačena diverzantska grupa „ustaša” maskiranih „crnim kapama i srpskim oznakama”. Prelazak hrvatskih postrojbi s tenkovima Vrcelju je potvrdio i komandant 2. bataljuna u Maloj Solini rezervni kapetan Rade Padežanin. ${ }^{46}$

${ }^{41}$ MARINIĆ, Specijalna jedinica policije Osa, 52-55.

42 HR-HMDCDR-199, kut. 8, Dopis Organa bezbjednosti 7. OG, Organ bezbjednosti 7. OG, str. pov. br. 8-53, 12. 3. 1992.; Dopis Organa bezbjednosti 7. OG, Organ bezbjednosti 7. OG, str. pov. br. 8-49, 7. 3. 1992.; Izvješće operativnog tima Organa bezbjednosti, Organ bezbjednosti 7. OG, str. pov. br. 8-60, 22. 3. 1992.

43 MARINIĆ, Specijalna jedinica policije Osa, 52-55; VRCELJ, Rat za Srpsku Krajinu, 36.

${ }_{44}$ HR-HMDCDR-2, Ratni dnevnik 1. brigade TO Glina; HODALJ, „102. brigada HV u operaciji Vihor 1991. godine", 28.

45 HODALJ, „102. brigada HV u operaciji Vihor 1991. godine”, 28; MARIJAN, „102. brigada HV Novi Zagreb”, 31; MARINIĆ, Specijalna jedinica policije Osa, 54-55.

46 Vrcelj je za neke starješine brigade i 1. OG naveo pogrešna imena i prezimena. VRCELJ, Rat za Srpsku Krajinu, 33; HR-HMDCDR-2, 1. brigada TO Glina, kut. 1, Popis 2. i 3. bataljuna 
Glavno mjesto prijelaza 102. brigade u Šišincu bilo je na samoj granici sa 153. brigadom, a Gračanica je bila u zoni 153. brigade. Po slamanju otpora u Gračanici i Stankovcu dijelovi 102. brigade, odnosno 1. i 2. bojna te oklopnomehanizirana skupina, započeli su s prelaskom Kupe. Prema podatku s vojne karte glinske brigade, Kupu su oko 10 sati prešla četiri, a tijekom noći još šest hrvatskih tenkova. Na desnom boku napada 153. brigada, koja je po zadatku trebala ovladati Gračanicom, nije prešla Kupu na lokaciji Gajdekovo, zbog čega je zapovjednik brigade Stjepan Turčić u večernjim satima 12. prosinca smijenjen. ${ }^{47}$ Do 9 sati 12. prosinca 1. bojna 102. brigade prešla je Kupu i ušla u Stankovac iako je oko 8 sati otvorena minobacačka vatra po mjestu prijelaza. Treća je pak bojna uvedena na područje Vratečko - Slana, no nije napredovala jer most na ušću rijeke Gline u Kupu nije bio zauzet. ${ }^{48}$

Budući da su žičane veze bile pokidane, a ni radioveza nije funkcionirala, komandant 1 . brigade poslao je grupu teritorijalaca u izvid prema Gračanici, a komandi 3. bataljuna naložio neka pokuša stupiti u vezu s napadnutim suborcima. Potom je poslao kapetana Gorana Skakića s vozilom veze u Taborište. Komanda 2. bataljuna dojavila mu je da su dva hrvatska tenka u pokretu od Gračanice prema Stankovcu, na što je Vrcelj zapovjedio pripremu i djelovanje netrzajnoga topa po tenkovima. Komandant samohodnoga voda protuzračne obrane 57/2 kapetan Milan Božić odbio je posjesti položaj na Stankovačkom brdu, stoga je uhićen. Kapetan Padežanin naišao je na hrvatsku grupu vojnika, na koju nije djelovao misleći da se radi o „Mikijevoj grupi” (Siniša Martić „Šilt”), da bi zatim izvukao svoju postrojbu na brdo iznad Stankovca. Potpukovnik Vrcelj, imajući potonje u vidu, žurno je poduzeo potrebne mjere: u 9:30 poziva komandanta izviđačko-diverzantske grupe Općinskoga štaba TO Glina Dušana Malovića, kojega zatim upućuje u Slatinu da se ondje pridruži komandantu 3. bataljuna; inženjerijski vod na čelu s rezervnim potporučnikom Đorđem Niševićem u dvije grupe šalje u Malu Solinu i Zaloj da izvedu dopunsko protutenkovsko zaprečivanje pravaca, a vod vojne policije usmjerava u Taborište sa zadatkom da na uzvisini iznad Gračanice spriječi napredovanje hrvatskih snaga. Također je naložio komandantu čete u Slatini da prenese zahtjev komandantu tenkovske čete, koji je trebao odmah poslati tenk T-55 u Zaloj kao pomoć u deblokadi pripadnika brigade. Jedan pak teritorijalac obavještava Vrcelja da su u Gračanici poginuli svi osim njega. Vrcelj zatim šalje rezervnoga kapetana Vuka Ilića u potragu za „Šiltom” i njegovom grupom boraca,

1. brigade TO Glina; HR-HMDCDR-199, kut. 8, Izvješće operativnog tima Organa bezbjednosti, Organ bezbjednosti 7. OG, str. pov. br. 8-60, 22. 3. 1992.; HR-HMDCDR-2, Radna karta 1. brigade TO, početak 12. 12. 1991., završetak 13. 12. 1991.

47 HODALJ, „102. brigada HV u operaciji Vihor 1991. godine”, 24, 28; HODALJ, „102. brigada Hrvatske vojske u operaciji Vihor 1991. godine”, 178, 181; BOŽIĆ, GORŠETA, 153. velikogorička brigada HV, 203; HR-HMDCDR-2, Radna karta 1. brigade TO, početak 12. 12. 1991., završetak 13. 12. 1991.

48 MARIJAN, „102. brigada HV Novi Zagreb”, 30-31; HODALJ, „102. brigada HV u operaciji Vihor 1991. godine", 28. 
ali neuspješno; Martić će se naime pojaviti tek sutradan ujutro. Tijekom dana rezervni kapetan Đuro Diklić u dva je navrata slao vozila po mobilizacijskom području radi prikupljanja boraca, no odaziv je bio poražavajući. ${ }^{49}$ Tako su se već prvoga dana pokazale slabosti otprije uočene u redovima glinske brigade, koje su se očitovale u činjenici da su pojedinci i dijelovi postrojbe samovoljno napuštali položaje. ${ }^{50}$

Potpukovnik Vrcelj nazvao je oko 10 sati komandanta 1. OG i upoznao ga sa stanjem na bojištu, tražeći da mu kao ispomoć pošalje bataljun vojnika. General-major Špiro Niković pritom ga je upozorio da nikako ne otvara artiljerijsku vatru na hrvatske snage jer je u tijeku bio pokret tristotinjak vozila JNA iz Zagreba ka Karlovcu. Tijekom razgovora obećao mu je pomoć u vidu čete vojne policije. ${ }^{51}$

O borbama na Kupi obaviješten je i Općinski štab TO Glina, od kojega je zatraženo slanje odjeljenja vojne policije. Odjeljenje je po dolasku upućeno kao pojačanje u Zaloj. Načelnik štaba glinske brigade major Momčilo Bjelopetrović obavijestio je potpukovnika Vrcelja da je 3. četa razbijena i da se njezini borci povlače prema Zaloju i Taborištu. Prema radnoj karti glinske brigade, 11 vojnika povuklo se „bez većeg reda” oko 9 sati u Zaloj. Na Vrceljev zahtjev 592. motorizirana brigada poslala je snagama glinske Teritorijalne obrane vod protuoklopnih topova T-12 u Malu Solinu, a istovremeno je obavljena i priprema artiljerije glinske brigade. ${ }^{52}$

Oko 13:15 teritorijalci razbijenoga voda 3. čete TO pokušali su doći do komandanta Vasića budući da je u Gračanici prestala pucnjava, no nisu našli komandanta nego tek jednoga skrivenog pripadnika voda. Telefonske žice bile su presječene i nije bilo moguće uspostaviti vezu između postrojbi. Oni su u Gračanici oko 15 sati naišli na tri hrvatska tenka, pred kojima su se sklonili. Ipak, bili su uočeni, pa je posada jednoga tenka ispalila granatu na njihovo sklonište. Trojicu ranjenih glinskih boraca odmah su zarobili hrvatski vojnici i

49 VRCELJ, Rat za Srpsku Krajinu, 33-37; HR-HMDCDR-2, 1. brigada TO Glina, kut. 1, Popis pripadnika protuavionskog topa 57/2; Popis pionirskog voda 1. brigade TO Glina; Popis 2. i 3. bataljuna 1. brigade TO Glina; Ratni dnevnik 1. brigade TO Glina.

50 HR-HMDCDR-2, 1. brigada TO Glina, kut. 1, Informacija o pogibiji boraca brigade, Komanda 1. brigade TO Glina, str. pov. br. 02-61/1, 22. 12. 1991.

51 VRCELJ, Rat za Srpsku Krajinu, 35. Podatak o kretanju vozila JNA nije točan budući da je kolona vozila Centra vojnotehničkih škola Kopnene vojske JNA „General armije Ivan Gošnjak” iz Zagreba prema zapovijedi Komande Centra od 9. prosinca trebala započeti s pokretom 10. prosinca, a završiti ga najkasnije 11. prosinca u 24 h. Tijekom „Vihora” nisu korištena ni sredstva 4. oklopne brigade (Jastrebarsko) koja su već 13. studenog 1991. prešla preko Karlovca na područje pod kontrolom JNA i pobunjenih Srba. Njezina je kolona preko Vojnića i Gline stigla do Rujevca u općini Dvor na Uni, odakle je dio vozila nastavio za Tuzlu, a preostala borbena vozila željeznicom su prebacivana do istoga odredišta sve do jutra 19. studenog. MILJANOVIĆ, Poslednji raport iz Zagreba, 326-340; TAČIĆ, Stakleni tenkovi, 162, 175.

52 HR-HMDCDR-199, kut. 8, Izvješće operativnog tima Organa bezbjednosti, Organ bezbjednosti 7. OG, str. pov. br. 8-60, 22. 3. 1992.; HR-HMDCDR-2, Radna karta 1. brigade TO, početak 12. 12. 1991., završetak 13. 12. 1991.; VRCELJ, Rat za Srpsku Krajinu, 35. 
odveli u Šišinec. Pri odvođenju je jedan zarobljenik zapazio pored ceste trojicu u borbi poginulih suboraca. ${ }^{53}$

Oko 14 sati u komandu glinske brigade stigao je zamjenik komandanta 1 . OG pukovnik Mirko Raković u pratnji starješina iz sastava Operativne grupe - pukovnika Momira Vukadinovića, načelnika oklopno-mehaniziranih jedinica, i pukovnika Slobodana Vukosavljevića, načelnika artiljerije, a s njima je stigla i četa vojnika iz rezerve 1. OG. Raković je po dolasku zaustavio vod tenkova M-84 koji su bili u pokretu iz Vrginmosta prema Petrinji, zadržavajući ih u Glini, a četu vojnika odveo je u Malu Solinu. ${ }^{54}$

Budući da je do oko 18 sati stao napad hrvatskih postrojbi, komandantu 2. glinskog bataljuna dopušteno je da izvuče 2. četu iz okolice Stankovca na rezervne položaje koji su posjednuti u 19 sati. Istovremeno komandant Općinskoga štaba TO Glina na Vrceljev zahtjev šalje grupu boraca u Hađer radi osiguranja puta $\mathrm{k}$ Stankovcu. Zapovijedanje u zoni odgovornosti 2. bataljuna kao i nad pristiglim pojačanjima potom je preuzeo pukovnik Raković. Tijekom noći nije bilo borbi, nego su obavljane pripreme za napad sljedećega dana. Pripremama se odazvao i Milan Vukšić, komandant čete boraca iz Majskih Poljana i Brnjeuške poznatijih kao „Vukšićeva četa”. ${ }^{55}$

Pred sumrak prvoga dana glinski teritorijalac Dragiša Drašković krenuo je sa suborcem kao prethodnica u Gračanicu, gdje su naišli na četvoricu hrvatskih vojnika koji su se kretali cestom. Oni su ga uočili i pozvali na predaju, no Drašković se spustivši oružje bacio u stranu i uspio pobjeći. Povratkom u postrojbu saznao je da su se dvojica od petorice teritorijalaca po mraku izvukla iz sela. Trojica su pak stradala u vlastitom minskom polju, pri čemu su dvojica poginula, a jedan je bio teško ranjen u obje noge. Drašković se vraća s nekoliko suboraca i uspijeva izvući ranjenoga Vladu Roksandića, a poginuli su ostali u minskom polju. Povlačenje petorice vojnika iz Gračanice tijekom noći potvrđuje i podatak s radne karte glinske brigade. ${ }^{56}$

Navečer 12. prosinca oko 19 sati u komandu glinske brigade stigao je iz Donjih Jama zamjenik komandanta 1. čete 2. bataljuna rezervni potporučnik Željko Vukičević, izvještavajući da je ondje veći dio čete napustio položaj, izuzev komandanta čete rezervnoga poručnika Nikole Baltića i 12 boraca. Radna karta glinske brigade donosi podatak da su se tijekom dana u Glinu povukla tri vojnika iz 3. bataljuna, 28 vojnika iz Donjih Jama te 18 vojnika iz Stankovca.

53 HR-HMDCDR-199, kut. 8, Izvješće operativnog tima Organa bezbjednosti, Organ bezbjednosti 7. OG, str. pov. br. 8-60, 22. 3. 1992.; Dopis Organa bezbjednosti 7. OG, Organ bezbjednosti 7. OG, str. pov. br. 8-49, 7. 3. 1992.

54 VRCELJ, Rat za Srpsku Krajinu, 37.

55 HR-HMDCDR-2, 1. brigada TO Glina, kut. 1, Ratni dnevnik 1. brigade TO Glina; Radna karta 1. brigade TO, početak 12. 12. 1991., završetak 13. 12. 1991.; VRCELJ, Rat za Srpsku Krajinu, 37-38.

56 HR-HMDCDR-40, kut. 24, M. D., „Slučajno živ”, Srpski glas (Glina), 26. 1. 1992., 5; HRHMDCDR-2, Radna karta 1. brigade TO, početak 12. 12. 1991., završetak 13. 12. 1991.; HRHMDCDR-2, 1. brigada TO Glina, kut. 1, Komanda 1. brigade TO Glina, Uvjerenje o ranjavanju, pov. br. 02-266/4, 17. 4. 1992. 
Pukovnici Vukadinović i Vukosavljević pomagali su potpukovniku Vrcelju u organizaciji protunapada, a oko 22 sata u komandu su stigli komandant Štaba TO 3. operativne zone pukovnik Rade Vujaklija i načelnik Štaba pukovnik Milan Begović. Ti su starješine u suglasju sa starješinama 1. OG savjetovali Vrcelja da se zbog nejasne situacije i noćnih uvjeta uspostavi veza i naredi organizacija obrane okruženih snaga te tijekom noći stvore slobodne snage za deblokadu boraca u okruženju. Potpukovnik Vrcelj stoga je poslao majora Bjelopetrovića u Taborište, u komandu 3. bataljuna, a na zapovjedno mjesto 2. bataljuna otišao je pukovnik Raković. ${ }^{57}$ Načelnik tehničke službe glinske brigade poslao je hitan zahtjev vojnom skladištu Javornik, u skladu s dozvolom Komande 1. OG, u kojem se tražila veća količina pješačkoga streljiva, protupješačkih mina, metaka za netrzajni top kalibra $82 \mathrm{~mm}$ te 192 rakete za višecijevni bacač $128 \mathrm{~mm}$ „Plamen” i 128 granata za haubice $155 \mathrm{~mm}$, što je, prema dopisanoj bilješci, „rešeno dana 13. 12. 1991." ${ }^{28}$

$\mathrm{Na}$ lijevom boku operacije, na petrinjskoj bojišnici, istodobno je trajao napad hrvatskih snaga. Druga bojna 144 . brigade zajedno sa 2 . A brigadom trebala je napasti na pravcu Slana - Glinska Poljana - Graberje, a preostali dio brigade bio je u pričuvi i spremnosti za borbu. Bojna je 12. prosinca prebačena u Slanu i ondje zaposjela položaj, no nije borbeno djelovala. ${ }^{59}$ Napad na pravcu Međurače - Pribilović brdo - Gora i pomoćnom pravcu Mokrice - Župić bio je zadatak 145. brigade HV-a sa 1. vodom 2. satnije 1. bojne 2. A brigade i 1 . bojnom 100. brigade HV-a. ${ }^{60}$ Tijekom prvoga dana na pravcu prema Glinskoj Poljani hrvatske su postrojbe uspješno napredovale potiskujući pripadnike 592. motorizirane brigade te su do noći stigle pod crkvu sv. Katarine. Na položaj je potom uvedena 2. satnija 2. bojne 2. A brigade. ${ }^{61}$ Prema podatku s radne karte glinske brigade, u 11 sati preko Kupe na područje Donjih Jama ubačeno je oko 50 hrvatskih vojnika. ${ }^{62}$ Uspješnost i snagu hrvatskoga napada potvrđuje i podatak o četi vojnika iz 592. motorizirane brigade koja se zbog straha i gubitaka povukla pješke prema Bosanskom Novom, ali je u selu Dragotina bila zaustavljena i vraćena u postrojbu. ${ }^{63} \mathrm{Da}$ bi se zaustavio daljnji prodor hrvatskih snaga, srpska je strana jakim artiljerijskim udarima djelovala po položajima i postrojbama HV-a. Komanda 592. motorizirane brigade već je 13. prosinca

57 HR-HMDCDR-2, 3. operativna zona TO SAO Krajina, kut. 1, Izvješće komandanta Štaba TO 3. operativne zone o stanju u 1. brigadi TO, Štab TO 3. operativne zone Banija i Kordun, br. 293, 25. 12. 1991.; Radna karta 1. brigade TO, početak 12. 12. 1991., završetak 13. 12. 1991.; VRCELJ, Rat za Srpsku Krajinu, 37; HR-HMDCDR-2, 1. brigada TO Glina, kut. 1, Popis 1. čete 2. bataljuna 1. brigade TO Glina.

58 HR-HMDCDR-2, 1. brigada TO Glina, kut. 1, Zahtjev načelnika tehničke službe 1. brigade TO, Komanda 1. brigade TO, pov. br. 03-50-4, 12. 12. 1991.

59 MARIJAN, 144. brigada HV Sesvete, 31.

60 STIPČIĆ, Zagrebački korpus Zbora narodne garde, 124; GAJDEK, Petrinjska bojišnica 1991. - 1995., 124.

${ }^{61}$ BUDIMIR, Rat i sloboda, 144; GAJDEK, Petrinjska bojišnica 1991. - 1995., 215-216.

62 HR-HMDCDR-2, Radna karta 1. brigade TO, početak 12. 12. 1991., završetak 13. 12. 1991.

63 HR-HMDCDR-199, kut. 5, 1. operativna grupa, kut. 1, Dopis Komande 1. OG, Komanda 1. OG, Organ bezbjednosti, str. pov. br. 1-55, 15. 12. 1991. 
zatražila od uprave 993. pozadinske baze da popuni brigadu streljivom iz skladišta Javornik, i to raznovrsnim streljivom za tenkove te većim brojem granata za haubice kalibra $122 \mathrm{~mm}$ (400 komada) i minobacače kalibra $120 \mathrm{~mm} .{ }^{64}$

Drugi dan - protunapad srpskih snaga

Po procjeni komande glinske brigade, hrvatske su snage tijekom noći ubacile preko mostobrana $200-300$ vojnika. ${ }^{65}$ Rano ujutro 13 . prosinca, prije 5 sati, potpukovnik Vrcelj zatražio je preko Sekretarijata narodne obrane Općine Glina da se hitno prikupe svi sposobni muškarci za obranu napadnutoga teritorija. ${ }^{66}$ Pukovnik Begović zatražio je pak hitno pozivanje Siniše Martića „Šilta” i komandanta izviđačko-diverzantske grupe Općinskoga štaba TO Glina. Grupa je u 8 sati upućena u Zaloj, u zonu 3. bataljuna, radi sudjelovanja u napadu na hrvatske snage. Šiltova skupina upućena je pukovniku Rakoviću, na prostor sjeverno od Hađera, radi ostvarenja istoga cilja. Specijalna milicija iz sastava Stanice javne bezbjednosti Glina otpratila je vod tenkova M-84 do Male Soline, u zonu 2. bataljuna. ${ }^{67}$ Prikupljene snage jačine jedne čete, sastavljene od izviđačko-diverzantske grupe Općinskoga štaba TO Glina (14 boraca), odjeljenja vojne policije (10 vojnika) i grupe boraca iz sastava 3. bataljuna, trebale su djelovati, koristeći zarobljeni tenk, na pravcu Zaloj - Gračanica. ${ }^{68}$ Tenk je naime zarobila manja grupa teritorijalaca kod srušenoga mosta između Zaloja i Gračanice. To je izvedeno lukavstvom vodnika Vlade Jaglića, pomoćnika komandanta za moral u 3. bataljunu. Jaglić je prišao dvojici tenkista s četvoricom boraca i predstavio se kao hrvatski vojnik govoreći kajkavskim dijalektom, a potom ih je nakon kratkoga razgovora usmrtio iz neposredne blizine. ${ }^{69}$ Tenkovska posada glinske brigade izvukla je zarobljeni tenk T-55 u Andrijeviće i osposobila ga za borbeno djelovanje. U rano jutro 13. prosinca tenk je upotrijebljen protiv hrvatskih snaga u Gračanici, na koje je ispalio čitav borbeni komplet streljiva. ${ }^{70}$ Drugi je glinski bataljun, na pravcu prema Stankovcu, ojačan snagama 3. „Vukšićeve” čete (70 boraca), četom vojne policije

${ }^{64}$ LUCIĆ, 2. gardijska brigada Hrvatske vojske Gromovi, 200; HR-HMDCDR-199, kut. 26, Zahtjev Komande 592. mtbr, Komanda 592. mtbr, pov. br. 12-232/18, 13. 12. 1991.

${ }_{65}$ HR-HMDCDR-2, Radna karta 1. brigade TO, početak 12. 12. 1991., završetak 13. 12. 1991.

${ }_{66}$ HR-HMDCDR-2, Općina Glina, kut. 1, Izvješće centra za obavješćivanje Općine Glina za dan 12. 12. 1991.

67 HR-HMDCDR-2, 3. operativna zona TO SAO Krajina, kut. 1, Izvješće komandanta Štaba TO 3. operativne zone o stanju u 1. brigadi TO, Štab TO 3. operativne zone Banija i Kordun, br. 293, 25. 12. 1991.; HR-HMDCDR-2, 1. brigada TO Glina, kut. 1, Ratni dnevnik 1. brigade TO Glina.

68 HR-HMDCDR-2, 1. brigada TO Glina, kut. 1, Ratni dnevnik 1. brigade TO Glina.

${ }^{69}$ HR-HMDCDR-2, 24. pješačka brigada TO, kut. 1, Prijedlog za proizvođenje-unapređivanje, Komanda 24. brigada TO br. 01-249/47, 1. 7. 1992.; HR-HMDCDR-18, „Podvig Vlage Jaglića”, Glas (Banja Luka), 7. 1. 1992., 4; Mladen MUTIĆ, „Ne diraj u Baniju”, Narodna armija (Beograd), 13. 2. 1992., 25; VRCELJ, Rat za Srpsku Krajinu, 36.

70 HR-HMDCDR-2, 1. brigada TO Glina, kut. 1, Ratni dnevnik 1. brigade TO Glina; Izvješće posade tenka 1. brigade Glina TO, nedatirano. 
(60 vojnika), trima tenkovima M-84, vodom specijalaca Stanice javne bezbjednosti Glina (20 policajaca, dva transportera), specijalnom jedinicom „Šiltovi” (40 boraca) te oko 110 boraca pod vodstvom pukovnika Radakovića. ${ }^{71}$ Slične podatke donosi i naknadno izvješće pukovnika Vujaklije, prema kojem su na stankovačkom pravcu napadale snage sastavljene od glinskih teritorijalaca, „Šiltova” (40 boraca), 60 pripadnika milicije i čete vojne policije 1. OG. Potpukovnik Vrcelj odredio je „Šiltovima” da se kreću na začelju kolone da „ne bi nešto iskomplikovao". ${ }^{72}$

Sam protunapad otpočeo je oko 9 sati 13. prosinca nakon vatrene pripreme topništva 592. i glinske brigade. Dužnost komandanta mješovitoga artiljerijskog divizijuna glinske brigade obnašao je rezervni poručnik Dušan Davidović, komandanta baterije $105 \mathrm{~mm}$ rezervni potporučnik Dragiša Galić, baterije 155 mm rezervni potporučnik Zoran Čučilović, baterije VBR 128 mm rezervni potporučnik Đuro Zinaja, a baterijama minobacača zapovijedali su rezervni potporučnici Jovica Vinčić i Zoran Arbutina. ${ }^{73}$ Snažno granatiranje dvaju sela i mjesta prijelaza omogućilo je brzo napredovanje prikupljenih snaga, koje su iz dva smjera napale neutvrđene i nedovoljno organizirane pripadnike 102. brigade HV-a. Uslijedilo je povlačenje u rasulu vojnika te brigade, na što je znatno utjecala pojava i vatreno djelovanje tenkova M-84. Borci 2. bataljuna i „Šiltovi” zauzeli su Stankovac bez gubitaka, a 3. četa zauzela je položaje iznad sela. Pripadnici izviđačko-diverzantske grupe, nadolazeći iz Zaloja, ušli su u dio Gračanice, odnosno u nekoliko kuća, gdje su pronađeni poginuli teritorijalci. Borbe su okončane oko 16 sati 13. prosinca. Borci 3. čete 2. bataljuna učvrstili su potom položaje u Stankovcu. Vrcelj je 14. prosinca naredio da 3. četa 1. bataljuna posjedne položaj iznad Gračanice, no prema podatku s radne karte, obrana je stabilizirana upućivanjem 2. čete 1 . bataljuna glinske brigade u 12 sati istoga dana. ${ }^{74}$

Pripadnici 1 . bojne 102 . brigade i oklopno-mehanizirane satnije dočekali su pak jutro 13. prosinca u Stankovcu, na temperaturi od oko $-15{ }^{\circ} \mathrm{C}$. Zapovjednik OGSB-a pukovnik Božo Budimir osobno je 12. prosinca došao u Stankovac i promijenio zadatak 102. brigade: naredio je da 2. bojna uđe u Gračanicu i zaštiti desni bok brigade, a da 1. i 3. bojna nastave napad na glavnom pravcu. Zapovjedniku 36. inženjerijsko-pontonirskog bataljuna naložio je da

${ }^{71}$ HR-HMDCDR-2, 1. brigada TO Glina, kut. 1, Ratni dnevnik 1. brigade TO Glina; Radna karta 1. brigade TO, početak 12. 12. 1991., završetak 13. 12. 1991.; VRCELJ, Rat za Srpsku Krajinu, 38.

72 HR-HMDCDR-2, 3. operativna zona TO, kut. 1, Izvješće komandanta Štaba TO 3. operativne zone za Baniju i Kordun o stanju u 1. brigadi TO, Štab TO 3. operativne zone Banija i Kordun, br. 293, 25. 12. 1991.; HR-HMDCDR-18, Čedomir POPOVIĆ, „Napad u svitanje”, Narodna armija (Beograd), 30. 1. 1992., 22; VRCELJ, Rat za Srpsku Krajinu, 38.

73 VRCELJ, Rat za Srpsku Krajinu, 38-39; HR-HMDCDR-2, 1. brigada TO Glina, kut. 1, Podaci za starješine, Komanda 1. brigada TO Glina, str. pov. br. 06-65/1, 24. 12. 1991.

74 HR-HMDCDR-2, 1. brigada TO Glina, kut. 1, Ratni dnevnik 1. brigade TO Glina; 3. operativna zona TO SAO Krajina, kut. 1, Štab TO 3. operativne zone Banija i Kordun, Telegram komandanta Štaba TO 3. operativne zone, 14. 12. 1991.; Radna karta komandanta Marka Vrcelja, početak 13. 12. 1991., završetak 17. 12. 1991.; VRCELJ, Rat za Srpsku Krajinu, 38-39. 
ostavi dovoljan broj sredstava za prelazak Kupe. Na mjestu prijelaza ostalo je pet-šest desantnih čamaca s izvanbrodskim motorima. Nestanak skele za prijelaz i plivajućega transportera te artiljerijsko djelovanje po mjestu prijelaza primorali su hrvatske vojnike da plivajući po velikoj hladnoći prijeđu na lijevu obalu Kupe. Pripadnici oklopno-mehanizirane satnije također su se povukli, onesposobivši prethodno borbena vozila. Prema dnevnom izvješću Operativnoga centra Glavnoga stožera HV-a, postrojbe 102. brigade napustile su svoje položaje uslijed jake artiljerijske vatre. Na bojište je u međuvremenu poslan zamjenik zapovjednika OGSB-a, koji je trebao usmeno narediti zapovjedniku oklopno-mehanizirane satnije da podrži pješaštvo, no to nije bilo moguće provesti jer je dotični samovoljno onesposobio tenkove i borbena vozila pješaštva. Stoga je zapovjedništvu 2. A brigade i organu sigurnosti zapovjedništva usmeno naloženo da se zapovjednika bojne Ivana Čeaka uhiti, a na njegovo mjesto postavi novi zapovjednik. ${ }^{75} \mathrm{Načelnik} \mathrm{veze} \mathrm{OGSB-a} \mathrm{toga} \mathrm{se} \mathrm{prijepodneva} \mathrm{našao}$ na mjestu događaja, gdje je susreo kaotično stanje i izbezumljene vojnike, od kojih je dio bio posve mokar s odjećom skorenom od smrzavanja. Područje prijelaza bilo je izloženo snažnom granatiranju: „Ne osvrćemo se puno, pogledom se traži samo naredni zaklon... i suhi i mokri i smrznuti, svi traže, svi traže mjesto što dalje od prijelaza i od Kupe." ${ }^{\text {76 }}$ Pošto je dobio izvješća od postrojbi da na lijevoj obali nema hrvatskih vojnika, pukovnik Budimir izdao je u Šišincu u 17 sati 13. prosinca usmenu zapovijed o okončanju operacije na tom dijelu bojišta. ${ }^{77}$

Borbe na smjeru prema Glinskoj Poljani nisu prestajale te su hrvatske postrojbe nastavile uspješno djelovati i zauzimati uzvisine važne za kontrolu petrinjske bojišnice. Na smjeru napada djelovale su snage 2. A brigade uz potporu oklopa, pod zapovijedanjem Drage Matanovića. Četrdesetak je „Gromova” između 10:30 i 15 sati 14. prosinca napadnim djelovanjem ovladalo područjem kod crkve sv. Katarine te prostorima po dubini Careva brda. Sutradan, 15. prosinca, dvadesetak gardista ulazi u, od srpskih snaga napuštenu, Glinsku Poljanu. Hrvatske snage potom su se počele utvrđivati na novim položajima, na potezu Ančićevo vrelo - Žunci - Carevo brdo. Rano ujutro 14. prosinca pripadnici 74. samostalnog bataljuna i 1. satnije 3. bojne 145. brigade ovladali su Šestanj brdom. ${ }^{78}$

75 HR-HMDCDR, Zbirka gradiva o Domovinskom ratu prikupljena iz privatnih izvora, Dnevno izvješće Zapovjedništva OZ Zagreb Operativnom centru GS HV, kl. 800-01/91-05, ur.br. 5120-04/91-1237, 13. 12. 1991.; MARIJAN, „102. brigada HV Novi Zagreb”, 32-33; BOŽIĆ, GORŠETA, 153. velikogorička brigada HV, 197; LUCIĆ, 2. gardijska brigada Hrvatske vojske Gromovi, 69; HODALJ, „102. brigada HV u operaciji Vihor 1991. godine”, 28, 30.

76 GAŠLJEVIĆ, „Dnevnik jednog tekuta”, 237.

77 BUDIMIR, Rat i sloboda, 141.

78 LUCIĆ, 2. gardijska brigada Hrvatske vojske Gromovi, 49, 54, 200; BUDIMIR, Rat i sloboda, 144; GAJDEK, Petrinjska bojišnica 1991. - 1995., 215-217; HODALJ, „102. brigada HV u operaciji Vihor 1991. godine”, 31; KREŠIĆ, 145. brigada Hrvatske vojske, 48, 58; HR-HMDCDR, Zbirka gradiva o Domovinskom ratu prikupljena iz privatnih izvora, Dnevno izvješće operativnom centru Glavnog stožera Hrvatske vojske Zapovjedništva operativne zone Zagreb, klasa: 800-01/91-05, ur.broj. 5120-04/91-1237, 14. 12. 1991. 
Po prestanku borbi na Kupi izviđačka grupa Općinskoga štaba TO Glina dobila je oko 7 sati 14. prosinca zadatak da raščisti Gračanicu i pomogne u izvlačenju poginulih glinskih boraca, a 3. četi 1. bataljuna naloženo je da posjedne položaje iznad sela. „Šiltovi” su upućeni u Stankovac kao ispomoć 2. bataljunu u pretraživanju terena. U idućem je razdoblju formirana nova četa teritorijalaca u Gračanici, na čelu s kapetanom Đurom Ćupovićem, pomoćnikom načelnika štaba za obavještajne poslove. Strah kod tih teritorijalaca bio je velik te nisu htjeli ulaziti u selo. Najlošije stanje u borbenom rasporedu uočeno je u Zaloju, kod 2. čete 3. bataljuna, pa je potpukovnik Vrcelj naredio da se urede prednji položaji na sjeveroistočnim padinama sela kako bi se kontrolirao veliki međuprostor između Zaloja i Gračanice. ${ }^{79}$

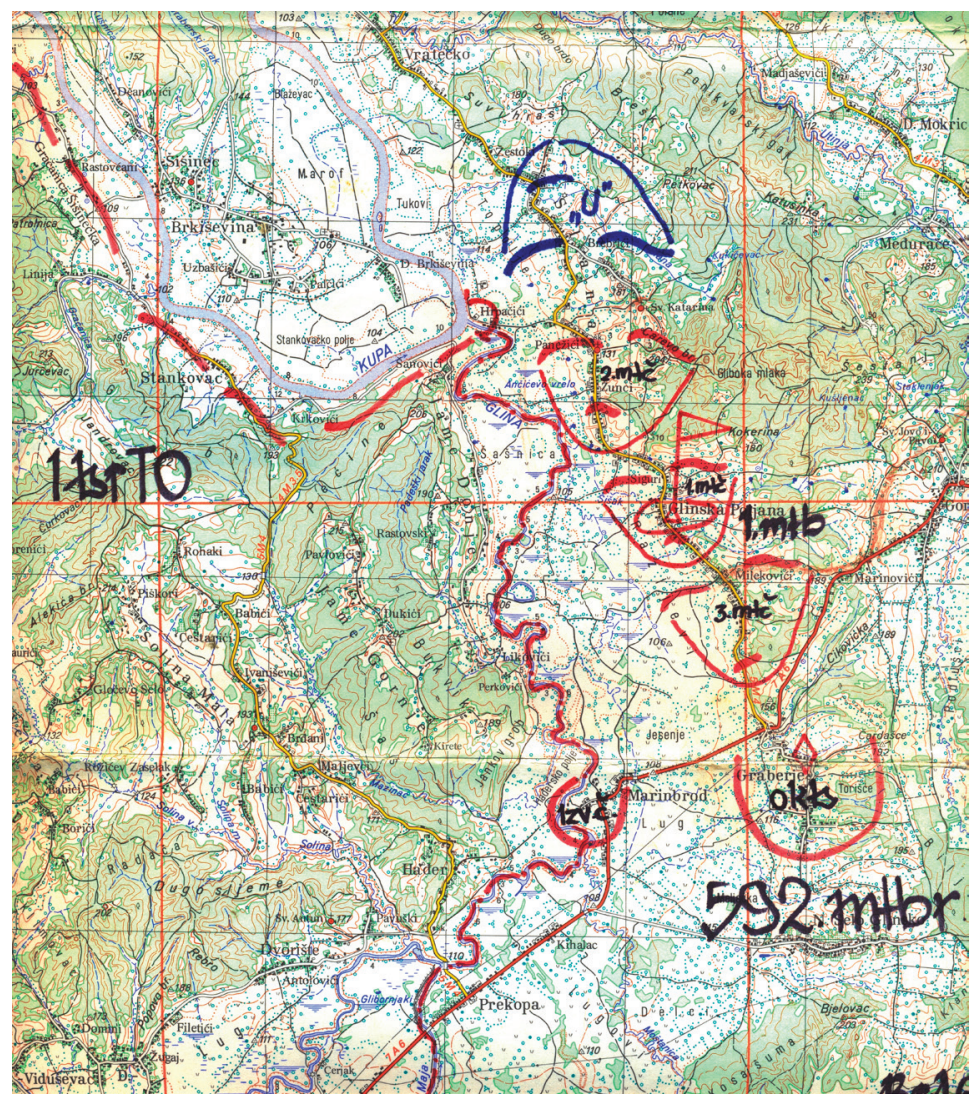

Karta 2. Protunapad srpskih snaga na Kupi 13. prosinca 1991.

Načelnik organa bezbjednosti 1. OG potpukovnik Milan Ostojić u dopisu od 15. prosinca istaknuo je veliki doprinos koji je u „odbijanju ustaša na svom pravcu dao [je] bataljon vojne policije" kojim je u borbi izravno zapovi-

79 HR-HMDCDR-2, 1. brigada TO Glina, kut. 1, Ratni dnevnik 1. brigade TO Glina. 
jedao pukovnik Mirko Raković. Beogradska Politika ocijenila je pokušaj nasilnoga prelaska Kupe kao „najžešću neprijateljsku ofanzivu od početka rata na Baniji”. ${ }^{80} \mathrm{U}$ krajinskom tisku i spisima glinske brigade iznošena je tvrdnja da je hrvatska napadna operacija nosila naziv „Una” jer joj je, kako su smatrali, osnovni cilj bio protjerivanje srpskoga stanovništva preko rijeke Une. ${ }^{81}$

Hrvatska je strana prepoznala više čimbenika kao razloge neuspjeha operacije, među kojima su posebno istaknuti: vrlo teški objektivni i subjektivni uvjeti koji su u vrijeme pripreme i provedbe operacije vladali na svim ratištima u Republici Hrvatskoj; nepripremljenost Zapovjedništva OGSB-a i 102. brigade HV-a za provedbu operacije; kratko vrijeme za organizaciju tako složene operacije; nedostatak temeljnih i posebnih vojno-stručnih znanja; nedovoljni broj stručnoga ljudstva u Zapovjedništvu OGSB-a; pogrešna procjena nekih ključnih elemenata, posebno spremnosti 102. brigade za izvedbu operacije; neodgovornost viših razina zapovijedanja i nedisciplina koja se pokazala u tome da pojedine postrojbe idu u akciju po vlastitoj volji. ${ }^{82}$

Zapovjedništvo 102. brigade i njezinih bojni nije bilo osposobljeno za provedbu tako zahtjevne operacije, a izostalo je i usklađivanje između zapovjednika postrojbi prije, za vrijeme i po završetku bojnih djelovanja. Nadalje, za trajanja operacije nije bilo nikakve koordinacije i veze s desnim i lijevim susjedom 102. brigade. Tako se 153 . brigada nije pokrenula u napad, a 2. bojna 102. brigade prekasno je i nepotpuno izvela prijelaz Kupe. Budući da se nije uspjelo na vrijeme neutralizirati srpsko topništvo na Svetoj Katarini, a nije zauzet ni most na ušću Gline u Kupu, 3. bojna nije pokrenuta u napad. Prva bojna 102. brigade s druge strane nije mogla zaustaviti srpske tenkove jer nije raspolagala sredstvima za protuoklopnu borbu, a zatražena topnička potpora preko sustava veze nije dobivena, što je potvrđeno i u kasnijoj analizi operacije. Skelski prijelaz je nestao, odnosno maknut je, što je dovelo do neorganiziranoga povlačenja ljudstva preko rijeke, a oklopna borbena vozila napuštena su i onesposobljena za upotrebu. ${ }^{83}$ Potpukovnik Vrcelj zaključio je pak da je hrvatski protivnik prikupio znatne snage, ali ipak nije uspio ovladati uzvisinama iznad Stankovca, odnosno Stankovačkim brdom, što bi, po njegovu mišljenju, bitno utjecalo na tijek operacije. ${ }^{84}$

\footnotetext{
${ }^{80}$ HR-HMDCDR-18, Đ. ĐUKIĆ, „Bojovnici u hladnoj Kupi”, Politika (Beograd), 15. 12. 1991., 8.

81 HR-HMDCDR-40, kut. 20, Bilten Ratnog predsjedništva i Štaba TO Opštine Glina (Glina), br. 5, 6-13; kut. 24, M. M., „Glina plače i pamti”, Srpski glas (Glina), 29. 12. 1991., 1; Veljko STAMBOLIJA, „U Krajini krvavi tragovi”, Srpski glas (Glina), 29. 12. 1991., 3-4; kut. 22, Vujo GAĆEŠA, „Palo 19 srpskih sinova”, Srpska nova riječ (Vojnić), 31. 12. 1991., 4; HR-HMDCDR-2, 1. brigada TO Glina, kut. 1, Informacija o pogibiji boraca brigade, Komanda 1. brigade TO Glina, str. pov. br. 02-61/1, 22. 12. 1991.

82 HODALJ, „102. brigada Hrvatske vojske u operaciji Vihor 1991. godine”, 182.

83 HREN, „Bili smo elitna postrojba”, 117; HODALJ, „102. brigada Hrvatske vojske u operaciji Vihor 1991. godine", 177.

84 VRCELJ, Rat za Srpsku Krajinu, 39.
} 
Nakon „Vihora” srpska je strana poteškoće prepoznala u širini zone odgovornosti od 29 kilometara koju je držala glinska brigada (povoljni uvjeti za ubacivanje hrvatskih izviđačko-diverzantskih grupa, stvaranje mostobrana, prelazak oklopnih borbenih vozila, grad Glina na dometu artiljerije), te ljudskom čimbeniku - nedovoljnoj osposobljenosti starješina za vođenje postrojbi, velikom neodazivu vojnih obveznika, bježanju s položaja, raznim oblicima nediscipline, neizvršavanju zadataka (posebno promatračko-izviđačkih), kao i izostanku osiguranja svih elemenata borbenoga rasporeda brigade. K tome je nedostajalo i slobodnih snaga kao odgovor na moguće borbene situacije. ${ }^{85}$ Stradanje teritorijalaca smatrano je posljedicom nepažnje, stražarske nebudnosti, nediscipline, alkoholizma te nedostatka ljudstva (od predviđenih 80, u postrojbi je bilo oko 40 boraca). ${ }^{86}$

Poredba gubitaka

Hrvatske postrojbe pretrpjele su tijekom operacije „Vihor” znatne gubitke, od kojih se najveći dio odnosio na 102. brigadu HV-a. Brigada je 14. prosinca izvijestila o četiri poginula, 17 nestalih i 19 ranjenih pripadnika ${ }^{87}$ Prema prvim izvješćima, gubici brigade iznosili su dva poginula, 50 lakše i teže ranjenih te 10 nestalih vojnika. ${ }^{8}$ Podaci OGSB-a od 14. prosinca govorili su nadalje o pet poginulih i 33 ranjena vojnika te brigade tijekom „Vihora”. Prema konačnim saznanjima, tijekom operacije stradalo je 13 (12 izravno, jedan preminuo od posljedica ranjavanja), a ranjeno 17 pripadnika 102. brigade. Imena poginulih su: Robert Bartolić, Nenad Bičanić, Boris Car, Nenad Cetin, Darko Koleno, Ivica Miketek, Mladen Rubić, Tomislav Sukobljević, Mario Tankov, Darko Šolić, Ivan Vučetić, Ante Zrile te Božo Širanović (od posljedica ranjavanja). Veći broj ranjenih i ozlijeđenih pripadnika 102. brigade zbrinut je i liječen u Medicinskom centru Sisak i ratnoj bolnici u Velikoj Gorici. Nekoliko poginulih hrvatskih vojnika pokopano je po Vrceljevoj zapovijedi u samoj Gračanici. ${ }^{89}$

Rano ujutro prvoga dana operacije u Gračanici je poginuo sisački specijalac Žarko Raf. ${ }^{90}$ Tijekom borbi smrtno su stradala dva, a ranjeno je više pripadnika 2. A brigade, a poginula su i četiri pripadnika tenkovske satnije „Gromova” - Damir Pokić i Siniša Janjić (12. prosinca 1991.) te Damir Sajko i Pave Žgela (13. prosinca 1991.). ${ }^{91}$ Dijelovi 2. bojne 102. brigade izloženi topničkoj

${ }_{85}$ HR-HMDCDR-6, kut. 1, Referat u Štabu TO RSK - organizacija TO na Baniji i Kordunu, Štab TO RSK, str. pov. br. 10/92, 11. 1. 1992.; HR-HMDCDR-2, 3. operativna zona TO SAO Krajina, kut. 1, Izvješće Štaba TO 3. operativne zone za Baniju i Kordun o stanju u 1. brigadi TO, Štab TO 3. operativne zone Banija i Kordun, br. 293, 25. 12. 1991.

86 VRCELJ, Rat za Srpsku Krajinu, 43; HR-HMDCDR-199, kut. 5, 1. operativna grupa, Dopis Komande 1. OG, Komanda 1. OG, Organ bezbjednosti, str. pov. br. 1-55, 15. 12. 1991.

87 HODALJ, „102. brigada HV u operaciji Vihor 1991. godine”, 30.

88 MARIJAN, „102. brigada HV Novi Zagreb”, 34.

89 Isto, 33-35; VRCELJ, Rat za Srpsku Krajinu, 44.

90 MARINIĆ, Specijalna jedinica policije Osa, 53.

91 LUCIĆ, 2. gardijska brigada Hrvatske vojske Gromovi, 199. 
vatri imali su u blizini Orlekovića 12 ranjenih boraca. ${ }^{92} \mathrm{Na}$ Šestanj brdu čitav je vod 145. brigade obolio od upale pluća uzrokovane velikom hladnoćom. ${ }^{93}$

Tijekom dva dana borbi poginula su ili umrla od posljedica ranjavanja ukupno 22 hrvatska vojnika - 13 pripadnika 102. brigade HV-a Novi Zagreb, šest pripadnika 2. A brigade ZNG-a „Gromovi”, dva pripadnika 78. samostalnog bataljuna Glina i jedan pripadnik Specijalne jedinice policije „Osa” Sisak. ${ }^{94}$ Od topničke vatre JNA u Nebojanu je 12. prosinca poginuo jedan pripadnik 144. brigade. U Šišincu je 13. prosinca teško ranjen pripadnik 153. brigade, koji je od posljedica preminuo krajem istoga mjeseca. ${ }^{95}$

Pored ljudskih, hrvatske postrojbe imale su i znatne gubitke oklopnih i drugih sredstava. U blizini Orlekovića oštećeno je šest motornih vozila. U kaotičnom povlačenju stradalo je šest vozila (četiri teško) te izgubljeno oko 90 komada pješačkoga oružja. Inženjerijsko-pontonirski bataljun izgubio je sedam čamaca. ${ }^{96}$ Pukovnik Vujaklija telegramom je obavijestio Štab TO Krajine o opkoljavanju hrvatskih snaga i čišćenju, pri čemu je „Zarobljen jedan ustaški tenk". ${ }^{97}$ „Šiltovi” su 14. prosinca nakon pretraživanja Stankovca u Glinu dovezli jedan tenk. Sljedećega je dana izvučen ,još jedan OT” (oklopni transporter). Martić „Šilt” izjavio je pak novinarima Srpske nove riječi da su zarobili dva tenka. ${ }^{98}$ Komanda 5. vojne oblasti JNA obavijestila je podređene postrojbe da je na Kupi zarobljeno pet, a uništeno sedam hrvatskih tenkova. Potpukovnik Vrcelj zapisao je po okončanju borbi u ratnom dnevniku da su izvučena četiri tenka, od kojih je jedan upotrebljiv, a tri su odvezena na pregled; koji dan poslije iznio je podatak da su zarobljena četiri tenka i jedan oklopni transporter, a uništeno pet tenkova, dva oklopna transportera i jedno motorno vozilo. ${ }^{99}$ Četiri tenka T-55 uvrštena su po završetku borbi u sastav glinske brigade, u njezinu tenkovsku četu. Više mjeseci poslije, tijekom 15. i 16. srpnja 1992., u nazočnosti pripadnika Nigerijskoga bataljuna Zaštitnih snaga Ujedinjenih naroda iz Kupe su izvučena tri tenka T-55 te odvučena tenkom za izvlačenje u Glinu radi pregleda i osposobljavanja za upotrebu. U Gračanici su ostala dva tenka T-55, dva oklopna transportera i jedan kamion, koji su u konačnici uništeni zbog

92 MARIJAN, „102. brigada HV Novi Zagreb”, 31.

93 KREŠÍ́, 145. brigada Hrvatske vojske, 48.

94 „25. obljetnica vojno-redarstvene operacije 'Vihor' obilježena u Šišincu”.

95 MARIJAN, 144. brigada HV Sesvete, 31; BOŽIĆ, GORŠETA, 153. velikogorička brigada $H V, 377$.

96 MARIJAN, „102. brigada HV Novi Zagreb”, 31, 33; HODALJ, „102. brigada HV u operaciji Vihor 1991. godine", 31.

${ }_{97}$ HR-HMDCDR-2, 3. operativna zona TO SAO Krajina, kut. 1, Telegram komandanta Štaba TO 3. operativne zone za Baniju i Kordun, 14. 12. 1991.

98 HR-HMDCDR-2, 1. brigada TO Glina, kut. 1, Ratni dnevnik 1. brigade TO Glina; HRHMDCDR-40, kut. 23, Robert KORICA, Aleksandar ARBUTINA, „Otrov za ustaše zove se Šilt!", Srpska nova riječ (Vojnić), 3. 2. 1992., 5.

99 HR-HMDCDR-2, 1. brigada TO Glina, kut. 1, Ratni dnevnik 1. brigade TO Glina; Informacija o pogibiji boraca brigade, Komanda 1. brigade TO Glina, str. pov. br. 02-61/1, 22.12. 1991. 
opasnosti da se pokvari tenk za izvlačenje, kao i nemogućnosti da do njih priđe vučno vozilo. Prema izvješću iz rujna 1992., na tenkovima izvučenima iz Kupe koji su ušli u sastav tenkovske čete glinske brigade nedostajale su ciljne sprave, radiouređaji, puškomitraljezi kupole tenka (PKT) i protuavionski mitraljezi (PAM). ${ }^{100}$ Ako uzmemo u obzir sve navedene podatke, ukupno je izgubljeno/ zarobljeno najmanje devet tenkova i dva transportera HV-a, odnosno 10 tenkova ako se ovom broju pribroji i tenk zarobljen prvoga dana operacije.

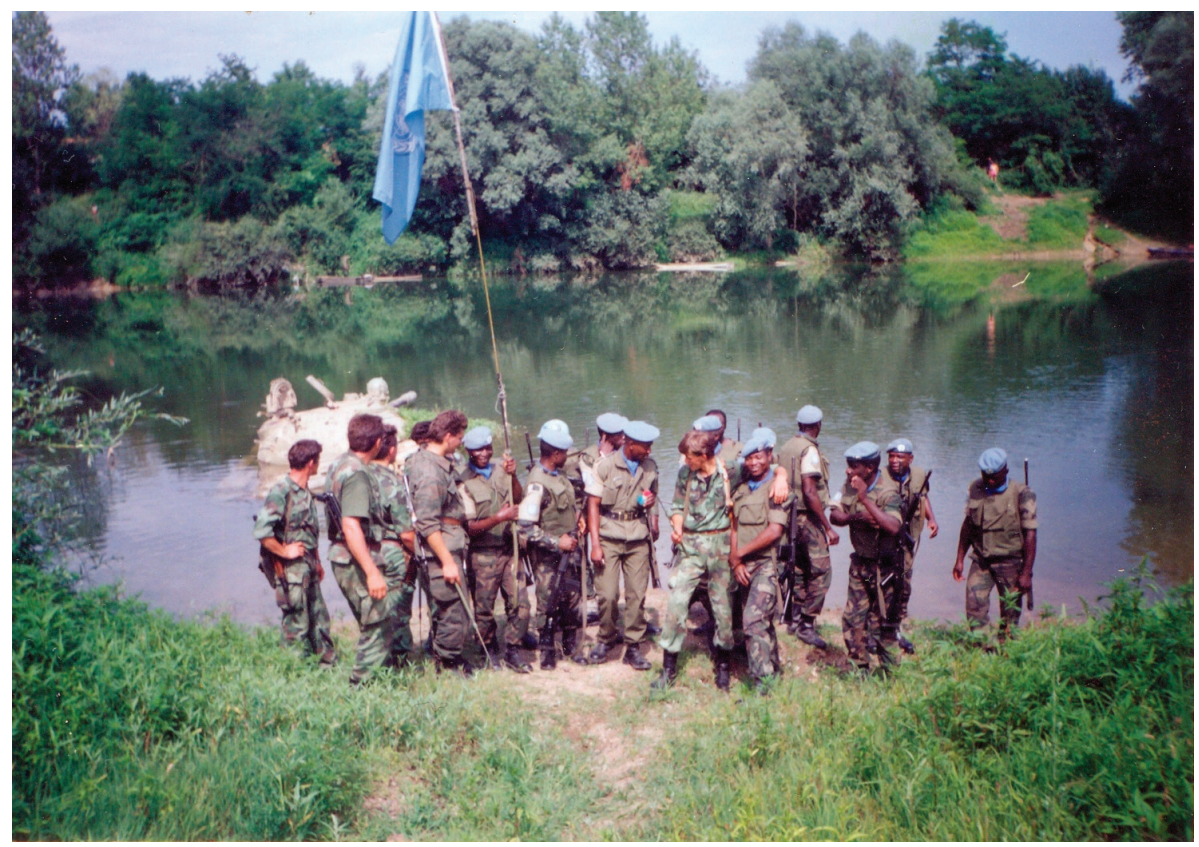

Slike 1-3. Srpski vojnici u nazočnosti pripadnika nigerijskog bataljuna UNPROFORa izvlače tenkove iz Kupe

I na drugoj strani, u redovima glinskih teritorijalaca i 592. motorizirane brigade, bilo je znatnih gubitaka. U Gračanici je poginulo 15 boraca 3. čete 3. bataljuna glinske brigade, među kojima i komandant čete potporučnik Nenad Borojević; najviše ih je stradalo u dvije kuće iz kojih su pružali otpor. Tri borca stradala su u proboju (dvojica u minskom polju), a jedan je poginuo prilikom zarobljavanja tenka HV-a. ${ }^{101}$ Dana 14. prosinca u Medicinski centar

${ }^{100}$ HR-HMDCDR-2, 1. brigada TO Glina, kut. 1, Informacija o stanju u 1. brigadi TO, Komanda 1. brigade TO Glina, pov. br. 02-21/5, 12. 1. 1992.; 24. brigada TO, kut. 1, Redovno borbeno izvješće, br. 01-81/163, 17. 7. 1992.; Izvješće o realizaciji izvršenja mobilizacije, 24. brigada TO, br. 01-10-2, 11. 9. 1992.; DIMITRIJEVIĆ, Modernizacija i intervencija jugoslovenske oklopne jedinice, 289; MARIJAN, „102. brigada HV Novi Zagreb”, 33.

${ }^{101}$ HR-HMDCDR-2, 1. brigada TO, kut. 1, Zahtjev za oslobađanje od dužnosti komandanta 1. brTO „DS” Glina, Komanda 1. brigade TO Glina, str. pov. br. 01-46/6, 22. 12. 1991.; Informa- 

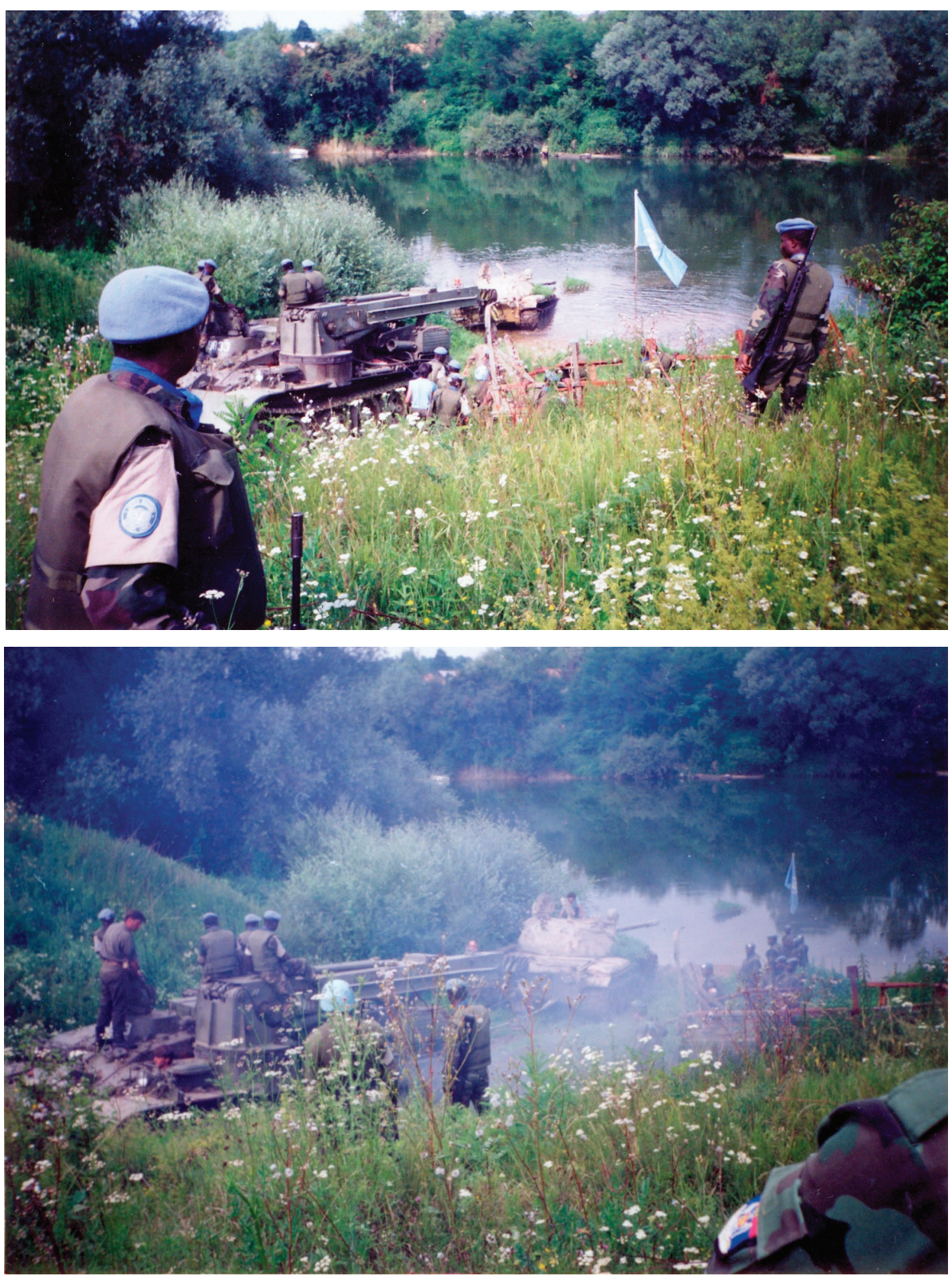

Glina dovezeno je 15 tijela, nad kojima je odmah obavljeno prepoznavanje, osim kod jednoga poginulog. ${ }^{102}$ Izvješće Štaba TO 3. operativne zone govorilo je o 19 poginulih, tri ranjena, jednom zarobljenom i četiri nestala borca.

cija o pogibiji boraca brigade, Komanda 1. brigade TO Glina, str. pov. br. 02-61/1, 22. 12. 1991.; VRCELJ, Rat za Srpsku Krajinu, 40.

${ }^{102}$ HR-HMDCDR-2, Općina Glina, kut. 1, Dnevno izvješće Centra za obavješćivanje Glina, 14. 12. 1991. 
Potpukovnik Vrcelj u svojim je dopisima tijekom prosinca 1991. nadređenim zapovjedništvima iznio brojku od 19 poginulih i dva ranjena pripadnika brigade. ${ }^{103}$ Prema kasnijim popisima, tijekom dvodnevnih borbenih djelovanja lakše su ili teže ranjena četiri glinska teritorijalca. ${ }^{104} \mathrm{U}$ raznim srpskim tiskovinama prenesen je podatak o 19 poginulih boraca, koji su, prema navodima izvjestitelja, većinom bili izmasakrirani, a manji je broj poginuo u borbi. ${ }^{105} \mathrm{U}$ upozorenju komandanta 5. vojne oblasti general-pukovnika Živote Avramovića od 17. prosinca govori se o nasilnom prelasku Kupe snaga HV-a, pri čemu je stradao jedan vod teritorijalaca koji se „bez ikakvog obezbeđenja” nalazio na odmoru po kućama u Gračanici, pri čemu je ubijeno 14, a nestalo 10 boraca, dok su hrvatski gubici procijenjeni na oko 200 poginulih. ${ }^{106} \mathrm{Na}$ petrinjskom dijelu pokupskoga bojišta tijekom dva dana borbi ranjeno je devet, a poginula su najmanje četiri vojnika iz sastava 592. motorizirane brigade. ${ }^{107}$

Prva satnija 2. bojne 102. brigade zarobila je kod Gračanice pet glinskih teritorijalaca, a 1 . satnija 1 . bojne 145 . brigade na pravcu prema Stankovcu zarobila je jednoga teritorijalca, koji je potom predan Vojnoj policiji Sisak. ${ }^{108} \mathrm{Za}$ robljeni vojnici bit će koji mjesec poslije razmijenjeni: 3. ožujka 1992. trojica, a još jedan 14. travnja 1992. godine. Jedan teritorijalac, inače pripadnik 2. čete 2. bataljuna, s protekom vremena bit će vođen kao poginuo, pa će broj poginulih u konačnici iznositi 20 boraca. ${ }^{109} \mathrm{Na}$ Svetoj Katarini 12. prosinca hrvatskim

${ }^{103}$ RUPIĆ, Republika Hrvatska i Domovinski rat, 552-553; HR-HMDCDR-2, Informacija o pogibiji boraca brigade, Komanda 1. brigade TO Glina, str. pov. br. 02-61/1, 22. 12. 1991.

${ }^{104}$ HR-HMDCDR-2, Općina Glina, kut. 1, Popis ratnih vojnih invalida 1990/94. Općine Glina; 1. brigada TO Glina, kut. 1, Uvjerenje, Komanda 1. brigade TO Glina, pov. br. 02-266/6, 17. 4. 1992.; Uvjerenje, Komanda 1. brigade TO Glina, pov. br. 02-266/4, 17. 4. 1992.; ŠTO Glina, kut. 1, Potvrda, 63/91, 26. 12. 1991.

${ }^{105}$ HR-HMDCDR-18, D. RAKAS, S. SIMIĆ, „Borba do posljednjeg metka”, Borba (Beograd), 16. 12. 1991., 4; Đ. ĐUKIĆ, „Glina se oprostila od svojih junaka”, Politika (Beograd), 17. 12. 1991., 8; HR-HMDCDR-199, kut. 5, 1. operativna grupa, Dopis Komande 1. OG, Komanda 1. OG, Organ bezbjednosti, str. pov. br. 1-55, 15. 12. 1991.

106 HR-HMDCDR-2, 6. mješoviti protuoklopni artiljerijski puk, kut. 1, Upozorenje 5. vojne oblasti, Komanda 5. VO, str. pov. br. 9/79-49, 17. 12. 1991., prijemni pečat: Komanda 6. mpoap, str. pov. br. 52-1, 18. 12. 1991.

107 HR-HMDCDR-199, kut. 26, Poimenični pregled gubitaka Komande 592. mtbr počev od 20. 10. 1991.; Uverenje VP 5552, pov. br. 781-8, 9. 5. 1992.; Uverenje VP 5552, pov. br. 781-6, 9. 5. 1992.; Uverenje VP 5552, pov. br. 781-5, 9. 5. 1992.; HR-HMDCDR, Baza stradalih na okupiranom području Republike Hrvatske; HR-HMDCDR, Zbirka gradiva o Domovinskom ratu prikupljena iz privatnih izvora, Dnevno izvješće Zapovjedništva OZ Zagreb Operativnom centru GS HV, kl. 800-01/91-05, ur.br. 5120-04/91-1237, 14. 12. 1991.

108 MARIJAN, „102. brigada HV Novi Zagreb”, 31; KREŠIĆ, 145. brigada Hrvatske vojske, 36.

109 HR-HMDCDR-2, 1. brigada TO Glina, kut. 1, Ratni dnevnik 1. brigade TO Glina; Uvjerenje, Komanda 1. brigade TO Glina, pov. br. 02-266/15, 17. 4. 1992.; Uvjerenje, Komanda 1. brigade TO Glina, pov. br. 02-266/1, 16. 4. 1992.; Uvjerenje, Komanda 1. brigade TO Glina, pov. br. 02-266/22, 17. 4. 1992.; 24. brigada TO, kut. 1, Govor komandanta brigade povodom prve godišnjice osnutka 1. brigade TO, Komanda 24. brigade TO, br. 01-23-2, 1. 11. 1992.; Zahtjev za razmjenu zarobljenika, Komanda 24. brigade TO, br. 02-32-1, 20. 11. 1992.; Uvjerenje, Komanda 24. brigade TO, br. 01-22-11, 24. 12. 1992.; Popis poginulih boraca, Komanda 24. brigade TO, br. 02-9-3, 28. 7. 1992.; Zonski štab TO Banija, kut. 1, Zahtjev za razmjenu zarobljenika, Komanda 24. brigade TO, br. 01-50-1, 21. 8. 1992., prijemni pečat ZnŠTO Banije, pov. br. 329-1, 
vojnicima predalo se šest vojnika JNA (dva Albanca, dva Srbina, Musliman i Makedonac), koje je potom potraživala Komanda 592. motorizirane brigade.

Jedan od zarobljenih vojnika bio je teže ranjen i prebačen u sisačku bolnicu; razmijenjeni su početkom ožujka 1992. godine. ${ }^{110}$

Ispraćaj 15 poginulih teritorijalaca iz Gračanice, koji je uz vatreni protuhrvatski govor predvodio episkop gornjokarlovački Nikanor, održan je 15. prosinca 1991. ispred Spomen-doma u Glini, a nazočnima se obratio i rezervni kapetan Mile Letica, podsjećajući ih na stradanja u glinskoj crkvi 1941. godine. ${ }^{111}$ Tijekom siječnja 1992. napisano je više tekstova posvećenih stradanju glinskih boraca u Gračanici, koje je proglašeno najtežim zločinom hrvatskih snaga tijekom ratne 1991. godine. Za hrvatsku stranu tvrdilo se da je postrojba od oko 500 ljudi ojačana tenkovskom četom potpuno razbijena, pri čemu je imala oko 150 mrtvih boraca. ${ }^{112} \mathrm{U}$ sjećanje na poginule glinske teritorijalce 24 . pješačka brigada u prosincu 1993. izdala je knjižicu Gračaničke žrtve sa slikama 19 poginulih, i to poimenično: Nenad Borojević, Dušan Borojević, Milan Bajlović, Đorđe Kovačević, Dušan Lalić, Bogdan Meandžija, Stanko Metikoš, Stevo Novaković, Ilija Pavlica, Ljuban Prusac, Dragan Radanović, Dragan Samac, Nikola Sarapa, Dragan Sladović, Boro Stambolija, Dušan Tintor, Pero Čučković, Stevan Šikanja i Slobodan Štulić. ${ }^{113}$

\section{Zaključak}

Krajem rujna i početkom listopada 1991. snage 1. OG izbile su na rijeku Kupu. Na petrinjskoj su pak bojišnici hrvatski branitelji uspjeli očuvati dijelove teritorija na desnoj obali Kupe, na području nebojanskoga džepa. Unatoč neuspjehu prvoga nasilnog prelaska Kupe kod mosta u Pokupskom, osmišljena je nova napadna operacija - „Vihor”, koja je otpočela 12. prosinca. Otpor manjega broja slabo utvrđenih pripadnika 1. brigade TO Glina brzo je slomljen,

21. 8. 1992.; Općina Glina, kut. 1, Popis poginulih boraca Općine Glina, nedatirano; Skupština općine Glina, red. broj: 06-71/94, 24. 2. 1994.; HR-HMDCDR-199, kut. 8, Izvješće operativnog tima Organa bezbjednosti, Organ bezbjednosti 7. OG, str. pov. br. 8-60, 22. 3. 1992.; Dopis Organa bezbjednosti 7. OG, Organ bezbjednosti 7. OG, str. pov. br. 8-53, 12. 3. 1992.; VRCELJ, Rat za Srpsku Krajinu, 33.

110 HR-HMDCDR-2, Dopis s podacima o zarobljenim vojnicima iz VP 5552, Vojna pošta 5552, int. br. 48-1, 12. 1. 1992.; HR-HMDCDR-199, kut. 8, Dopis Organa bezbjednosti 7. OG, Komanda 7. OG, Organ bezbjednosti, str. pov. br. 8-47, 7. 3. 1992.; Izvješće Organa bezbjednosti 592. mtbr, 7. 3. 1992., prijemni pečat: Organ bezbjednosti 7. OG, str. pov. br. 8-50, 8. 3. 1992.

111 „SPC: Srbi i Hrvati - Vjekovni neprijatelji”; HR-HMDCDR-40, kut. 20, Mile LETICA, „Život su izgubili za nas”, „Oproštaj od palih drugova”, Bilten Ratnog predsjedništva i Štaba TO Općine Glina (Glina), br. 5, 8-12.

${ }^{112}$ HR-HMDCDR-40, kut. 20, Veljko STAMBOLIJA, „U Krajini krvavi tragovi”, Mile LETICA, „Život su izgubili za nas”, „Oproštaj od palih drugova”, M. M., „Glina plače i pamti”, Bilten Ratnog predsjedništva i Štaba TO Opštine Glina (Glina), br. 5, 6-13; kut. 22, Vujo GAĆEŠA, „Palo 19 srpskih sinova", Srpska nova riječ (Vojnić), 31. 12. 1991., 4.

${ }^{113}$ HR-HMDCDR-2, 24. pješadijska brigada Glina, kut. 1, Gračaničke žrtve, 12. 12. 1993. 
što je omogućilo prelazak hrvatskih postrojbi preko rijeke. Starješine iz 1. OG i Štaba TO 3. operativne zone SAO Krajine istoga su dana pritekli u pomoć zapovjedniku glinske brigade u organizaciji snaga za protunapad. Trinaestoga prosinca 1991. prikupljene snage Teritorijalne obrane i JNA, uz jaku potporu artiljerije i voda tenkova M-84, protjerale su hrvatske postrojbe na lijevu stranu Kupe. Ipak, na petrinjskoj bojišnici hrvatske su snage postigle određeni uspjeh zauzevši Svetu Katarinu i Šestanj brdo, uz potiskivanje srpskih snaga iz Glinske Poljane.

U „Vihoru” su obje strane pretrpjele velike gubitke u ljudstvu, a hrvatske su snage $k$ tome izgubile i znatan broj oklopnih borbenih vozila. Srpski pobunjenici na Banovini smatrali su tu operaciju najžešćim hrvatskim napadom tijekom ratne 1991. godine. U borbenim djelovanjima pokazala se važnost iskusnih postrojbi: na hrvatskoj strani Posebne jedinice policije Policijske uprave Sisak i 2. A brigade ZNG-a „Gromovi”, a na srpskoj strani izviđačko-diverzantskih skupina i vojne policije 1 . OG.

Operacija „Vihor” doživjela je neuspjeh zbog neiskustva hrvatskih postrojbi koje su trebale biti udarna snaga prodora i nedoraslosti dijela zapovjedništava te Zapovjedništva OGSB-a za takvu vrstu operacije. Postrojbe HV-a nisu ostvarile dovoljno dubok ulazak u prostor i zaposjele položaje na Stankovačkom brdu, nisu organizirale borbeni raspored niti izvele zaprečivanje prilaza oslobođenim naseljima, a izostalo je i pravovremeno usklađivanje postrojbi u napadu. Nasuprot hrvatskim postrojbama nalazile su se pak dovoljno brojne srpske snage, sastavljene od glinskih teritorijalaca i postrojbi JNA, koje su imale premoć u artiljeriji i oklopništvu, a bile su predvođene iskusnim starješinama. Stoga je zamišljena operacija u konačnici polučila tek manje taktičke pomake na pokupskoj bojišnici.

\section{Arhivski i neobjavljeni izvori}

HR-HMDCDR: Hrvatska, Hrvatski memorijalno-dokumentacijski centar Domovinskog rata, Zagreb:

fond 2, Paradržavne i paravojne postrojbe na okupiranom teritoriju RH.

fond 6, Glavni štab Srpske vojske Krajine.

fond 18, Digitalna zbirka dokumenata.

fond 40, Zbirka tiskovina.

fond 199, 10. korpus.

Baza stradalih na okupiranom području Republike Hrvatske.

Zbirka gradiva o Domovinskom ratu prikupljena iz privatnih izvora. 


\section{Objavljeni izvori i tisak}

Bilten Ratnog predsjedništva i Štaba TO Opštine Glina (Glina), 1991, 1992.

Borba (Beograd), 1991.

BRIGOVIĆ, Ivan; RADOŠ, Ivan, ur. Republika Hrvatska i Domovinski rat 1990. - 1995. Dokumenti, knj. 19: 9. korpus JNA (1991.). Zagreb: Hrvatski memorijalno-dokumentacijski centar Domovinskog rata, 2016.

Glas (Banja Luka), 1992.

Hrvatski vojnik (Zagreb), 1992.

Narodna armija (Beograd), 1992.

PANDŽA, Ivica. Krajina kroz dokumente. Sisak: Agencija za istraživanje i dokumentaciju ratnih sukoba, 2014.

Politika (Beograd), 1991.

RUPIĆ, Mate, ur. Republika Hrvatska i Domovinski rat 1990. - 1995. Oružana pobuna Srba u Hrvatskoj i agresija oružanih snaga SFRJ i srpskih paravojnih postrojbi na Republiku Hrvatsku (1990. - 1991.), knj. 1. Zagreb: Hrvatski memorijalno-dokumentacijski centar Domovinskog rata, 2007.

Srpska nova riječ (Vojnić), 1991, 1992.

Srpski glas (Glina), 1991, 1992.

\section{Literatura}

„25. obljetnica vojno-redarstvene operacije 'Vihor' obilježena u Šišincu”. Udruga ratnih veterana 2. gardijske brigade „Gromovi”, 11. 12. 2016. Pristup ostvaren 21. 3. 2019. https://www.udruga2gbr-gromovi.hr/25-obljetnica-vojno-redarstvene-operacije-vihor-obiljezena-u-sisincu/.

ANDRES, Ladislav; HODALJ, Vlado; SELANEC, Drago; PEJNOVIĆ, Andrija; VIDOVIĆ, Davorko. 120. brigada HV-a „Ban Toma Bakač” - Sisak u Domovinskom ratu 1991. - 1993. godine. Sisak: Narodna knjižnica i čitaonica Sisak, 2010.

BARIĆ, Nikica. Srpska pobuna u Hrvatskoj 1990. - 1995. Zagreb: Golden marketing-Tehnička knjiga, 2005.

BOŽIĆ, Aleksandar; GORŠETA, Damir. 153. velikogorička brigada $H V$. Velika Gorica: Turopoljski glasnik u suradnji s Udrugom pripadnika 153. brigade $\mathrm{HV}, 2002$.

BRIGOVIĆ, Ivan; RADOŠ, Ivan. 101. brigada HV-a. Zagreb: UHBDR 101. brigade Susedgrad; Hrvatski memorijalno-dokumentacijski centar Domovinskog rata, 2013.

BUDIMIR, Božo. Rat i sloboda. Zagreb: Udruga branitelja iz Domovinskog rata, Operativna grupa za Sisak i Baniju; Branitelji Hrvatske, 2008.

DIMITRIJEVIĆ, Bojan. Modernizacija i intervencija jugoslovenske oklopne jedinice 1945-2006. Beograd: Institut za savremenu istoriju, 2010. 
GAJDEK, Đuro. Petrinjska bojišnica 1991. - 1995. Petrinja: Grad Petrinja, 2008.

GAŠLJEVIĆ, Marjan. „Dnevnik jednog tekuta”. U: Zapisi s Banovine: 1990., 1991., 1995., ur. Ante Nazor i Željka Križe. Zagreb: Hrvatski memorijalno-dokumentacijski centar Domovinskog rata, 2009, 95-259.

HODALJ, Vlado. „102. brigada HV u operaciji Vihor 1991. godine”. Polemos 2 (1999), br. 1-2: 11-41.

HODALJ, Vlado. „102. brigada Hrvatske vojske u operaciji Vihor 1991. godine”. U: 102. brigada HV Novi Zagreb, ur. Tomo Krešo Špeletić. Zagreb: Klub veterana 102. brigade HV, 2011, 153-184.

HREN, Alojzij. „Bili smo elitna postrojba”. U: 102. brigada HV Novi Zagreb, ur. Tomo Krešo Špeletić. Zagreb: Klub veterana 102. brigade HV, 2011, 116-122.

KREŠIĆ, Antun. 145. brigada Hrvatske vojske. Zagreb: Repro-Color, 2011.

LUCIĆ, Josip, ur. 2. gardijska brigada Hrvatske vojske Gromovi. Zagreb: Ministarstvo obrane Republike Hrvatske, Glavni stožer Oružanih snaga RH, 2011.

MARIJAN, Davor. „102. brigada HV Novi Zagreb”. U: 102. brigada HV Novi Zagreb, ur. Tomo Krešo Špeletić. Zagreb: Klub veterana 102. brigade HV, 2011, 21-91.

MARIJAN, Davor. 144. brigada HV Sesvete 1991. - 1995. Sesvete: Muzej Prigorja, 2007.

MARIJAN, Davor. Domovinski rat. Zagreb: Despot Infinitus; Hrvatski institut za povijest, 2016.

MARIJAN, Davor. Jugoslavenska narodna armija u ratu protiv Republike Hrvatske. Zagreb: Ministarstvo obrane RH, Glavni stožer Oružanih snaga RH; Hrvatsko vojno učilište „Petar Zrinski”, 2008.

MARIJAN, Davor. Slom Titove armije. Zagreb: Golden marketing-Tehnička knjiga, 2008.

MARIJAN, Davor. Smrt oklopne brigade. Zagreb: ZORO, 2002.

MARINIĆ, Borna. Specijalna jedinica policije Osa u Domovinskom ratu. Sisak: Udruga SJP OSA Sisak, 2018.

MILJANOVIĆ, Ratko T. Poslednji raport iz Zagreba. Beograd: Ratko T. Miljanović, 2016. NAZOR, Ante; BRIGOVIĆ, Ivan. Zapovjedni vrh JNA siječanj 1990. - svibanj 1992. Zagreb: Ministarstvo obrane Republike Hrvatske; Hrvatski memorijalno-dokumentacijski centar Domovinskog rata, 2010.

RADELIĆ, Zdenko; MARIJAN, Davor; BARIĆ, Nikica; BING, Albert; ŽIVIĆ, Dražen. Stvaranje hrvatske države i Domovinski rat. Zagreb: Školska knjiga, Hrvatski institut za povijest, 2006.

RUŽIĆ, Slaven. „Politički i vojno-sigurnosni aspekt zbivanja u glinskoj općini 1990. - 1991." Radovi Zavoda za hrvatsku povijest 47 (2015): 711-736. 
SABOLOVIĆ, Marin; SIKIRIĆ, Lucija; VUKOVIĆ, Goran. „Teorijski pregled vojno-geografskih analiza - primjer operacija Vihor". U: Vojno-geografski aspekti obrambenoga Domovinskog rata. Zbornik radova znanstveno-stručnog skupa, ur. Marin Sabolović. Zadar: Sveučilište u Zadru, 2017, 49-65.

„SPC: Srbi i Hrvati - Vjekovni neprijatelji”. YouTube. Pristup ostvaren 21. 3. 2019. https://www.youtube.com/watch?v=L26QurCtUG4.

STIPČIĆ, Rudi. Zagrebački korpus Zbora narodne garde 3. operativna zona Zagreb. Sisak: Karmen komunikacije, 2018.

TAČIĆ, Radovan. Stakleni tenkovi. Vršac: „Sloboda”, 1994.

VRCELJ, Marko. Rat za Srpsku Krajinu 1991-1995. Beograd: Srpsko kulturno društvo „Zora”, 2002. 


\section{SUMMARY}

\section{A Review of Operation Whirlwind (1991)}

By referring to original documents of the military and civilian institutions of the rebel Serbs as well as those of the Yugoslav People's Army, this paper outlines the state and the activity of the aggressor forces in the occupied area of the Glina and Petrinja Districts, where Operation Whirlwind was carried out in December 1991. The military activities of the Croatian forces in this part of the Pokuplje region that preceded the operation are also described. A thorough insight into the preparation and course of the enemy counterattack in Operation Whirlwind is given, with a comparison of losses on both belligerent sides. Considering everything stated, the aggressor's superiority in artillery and armour is obvious, as is the contribution of the Yugoslav People's Army in carrying out the counterattack.

Key words: Croatian Army; Yugoslav People's Army; Territorial Defence of the Serbian Autonomous Region of Krajina; Operation Whirlwind 